Marquette University

e-Publications@Marquette

Finance Faculty Research and Publications

Business Administration, College of

$1-1-2016$

\title{
Determinants of Industrial Property Rents in the Chicago Metropolitan Area
}

David E. Clark

Marquette University, david.clark@marquette.edu

Anthony Pennington-Cross

Marquette University, anthony.pennington-cross@marquette.edu

Accepted version. Regional Science and Urban Economics, Vol. 56 (January 2016): 34-45. DOI. (C) 2015 Elsevier. Used with permission 


\title{
Industrial Property Rents in the Chicago Metropolitan Area: Property and Property Clusters, Lease and Lease Term Structures, Location and the Local Market ${ }^{\text {th }}$
}

\author{
David Clark \\ Department of Economics, Marquette University \\ Milwaukee, WI \\ Anthony Pennington-Cross* \\ Department of Finance \& Center for Real Estate, \\ Marquette University \\ Milwaukee, WI
}

\begin{abstract}
Urban economists have long understood the theoretical importance of transportation infrastructure and accessibility on the location choice of households and firms. We utilize a readily available data set of transaction rents in the Chicago metropolitan area to investigate the determinants of industrial property rents. Among the factors considered are proximity to transportation infrastructure, characteristics of the property, the term structure of lease agreements, and local attributes of the neighborhood.
\end{abstract}


Empirical results suggest property, lease, and local demographics play important roles in determining rents. Despite the fact that industrial property tends to locate very close to rail lines and interstate highways, transportation infrastructure has much less influence. There is evidence that there is an upward sloping lease term structure premium and that the premium varies over time. The model is also used to develop a constant quality rent index for the Chicago commercial property market. Compared to average rents and asking rents, the estimated constant quality index shows a smaller run up in rents from 2003 through 2008 and a larger drop off in rents through the end of 2011.

Keywords: Commercial property; Lease term structure; Transportation infrastructure; Hedonic

\section{Introduction and motivation}

Urban location models emphasize the importance of accessibility in firm and household location choices. Transportation expenditures and logistic costs account for $4.8 \%$ and $7.7 \%$ of gross domestic product (GDP), respectively, ${ }^{2}$ making transportation a central component of total costs for most businesses and an important component of GDP for the nation as a whole. In this paper, we study the industrial property market in the Chicago metropolitan area. The dominant form of industrial property in Chicago is warehouses, which are quintessentially transportation hubs. They function as the location where goods are collected from input sources and distributed to retail locations or to other firms. In fact, approximately one third of all US rail freight originates in, passes through, or terminates in Chicago. In terms of container volume, Chicago is the fourth largest handler behind Hong Kong, Singapore, and Shanghai (DiJohn, 2010). In terms of square feet of leasable space in the Chicago metropolitan area, industrial property is much larger than office space or retail space. According to CoStar market reports, industrial property was $1,116,416,637$ square feet, office property was $461,145,884$ square feet, and retail property was $511,142,814$ square feet of rentable space in the fourth quarter of 2012. Clearly, warehouses and associated industrial properties are especially important components of the economy for cities like Chicago and their surrounding areas.

In this paper, we examine how property, location, and lease characteristics determine rents for industrial property in the Chicago metropolitan area. The paper contributes to current knowledge on the

Regional Science and Urban Economics, Vol 56 (January 2016): pg. 34-45. DOI. This article is (C) Elsevier and permission has been granted for this version to appear in e-Publications@Marquette. Elsevier does not grant permission for this article to be further copied/distributed or hosted elsewhere without the express permission from Elsevier. 
determinants of property rents by including a detailed examination of the value of different attributes of industrial properties using a hedonic regression analysis. We observe the clustering of industrial property around airports, rail lines, and interstate highways and ask whether there is any rent premium associated with this clustering. We also observe a variety of lease terms (i.e., the length of the lease contract). Empirical tests are conducted to evaluate the lease term structure premium and its stability over time. Finally, the hedonic findings are used to derive a constant quality rent index, which can be compared with the information that is typically used by market participants.

Commercial brokers and brokerage firms provide extensive information to potential clients on property availability, market conditions, and prospective rents at different locations. Brokerage real estate firms such as Cushman and Wakefield are a common source of rents that landlords offer tenants at the beginning of negotiations. This is often referred to as the "asking rent". In addition, brokers often post listings on a centralized web site such as CoStar, which also reports average rents for all transactions. However, does this information accurately reflect market conditions? One limitation of inter-temporal comparisons of average rents is that the average property may change qualitatively over time. We find that compared to the constant quality rents derived in this paper, average asking rents and average transaction rents overstated the increase in rents when the market was expanding and subsequently missed the timing of the peak of the real estate market cycle. This divergence can have implications for policies and programs targeting industrial properties, industrial-urban development, and the efficiency of industrial property markets.

\section{Relevant literature}

The role of rents in the urban environment and the capitalization of those rents into prices have been the subject of ongoing research for many decades. Indeed, von Thünen showed the link between agricultural land prices and proximity to markets in his book The Isolated State, in 1826 . The hedonic method was first used by Waugh (1928) to model agricultural markets, and it was further enhanced by Lancaster (1966) as well as Griliches, 1967 and Griliches, 1971. Rosen (1974) formalized a two-stage model to derive implicit market demand

Regional Science and Urban Economics, Vol 56 (January 2016): pg. 34-45. DOI. This article is @ Elsevier and permission has been granted for this version to appear in e-Publications@Marquette. Elsevier does not grant permission for this article to be further copied/distributed or hosted elsewhere without the express permission from Elsevier. 
functions and many subsequent studies have examined the role of both structural and site location attributes on property values. Recognizing that there are no explicit market values for specific characteristics (e.g., floor size) of certain goods or services (e.g., rental properties), hedonic pricing reveals the implicit prices for each individual attribute from the observed market value of the asset. In the context of leased space, the rental rate represents the value the renter places on the physical attributes of the space and building, the attributes of the location, and the attributes of the lease as well as the supply of these attributes in the market.

Rents are part of a larger structural model where firms must decide whether to own property or rent it while at the same time finding the best location and best lease structure. Similar to many prior research efforts, our research conducts a reduced form approach that analyzes the outcome (the rent level) that incorporates all of these factors. ${ }^{3}$ Although much of the prior hedonic research has focused on single-family residential property markets, there has been an increase in interest in commercial property values and rents(e.g., Ambrose, 1990, Brounen and Jennen, 2009, Chegut et al., 2011, Cutter and DeWoody, 2010, Fehribach et al., 1993, Slade, 2000, Munneke and Slade, 2000, Munneke and Slade, 2001, Sivitanidou and Wheaton, 1992, Sivitanidou and Sivitanides, 1995, Sivitanidou, 1995, Jennen and Brounen, 2009, Brunauer et al., 2010 and Conroy and Milosch, 2011) ${ }^{4}$, and some of that literature examines industrial property rents (Ambrose, 1990, Sivitanidou and Sivitanides, 1995, Sivitanidou, 1995 and Ryan, 2005). Most of these studies rely on a fairly small sample of observations that was accessed through a local brokerage firm. The findings are mixed. For example, Sivitanidou and Sivitanides (1995) examined the determinants of 461asking rents in Los Angeles. The results indicate that freeway density, proximity to freeway intersections, and proximity to a major airport all had a positive and significant impact on industrial rents. Sivitanidou (1995) finds similar results on warehouse and distribution asking rents in the Los Angeles area, but she finds differences between large (i.e., more than 45,000 sq. ft.) and small properties (i.e., between 10,000 and 45,000 sq. ft.) properties. Specifically, the impact of proximity to transportation infrastructure (i.e., airports, highways) is more pronounced for larger properties.

Regional Science and Urban Economics, Vol 56 (January 2016): pg. 34-45. DOI. This article is (c) Elsevier and permission has been granted for this version to appear in e-Publications@Marquette. Elsevier does not grant permission for this article to be further copied/distributed or hosted elsewhere without the express permission from Elsevier. 
Renters will only pay a premium for these types of locations if there is sufficient demand relative to the supply. Major international airports (e.g., LAX (Los Angeles international airport) and O'Hare) are just the types of locations that are likely to have some intrinsic value and are limited in supply. As a result, transportation related firms are likely to compete, bidding against each other to be close to large international airports and as a result, drive up rents. In contrast, interstate highways and railways are much more ubiquitous in most cities and metropolitan areas. Thus, we should expect that the premiums associated with these types of transportation infrastructure may be more muted or may not exist at all.

Finally, a number of studies examine the influence of the lease term structure (Ambrose and Yildirim, 2008, Bond et al., 2008, Clapham and Gunnelin, 2003, Englund et al., 2004, Englund et al., 2008 and Gunnelin and Soderberg, 2003) on property rents. Most of these studies find that there is a positive relationship between the length of the lease term and the rent. However, before the downturn in the early 1990s, long-term rents were lower than short term rents for office space in Stockholm Sweden. In general, the evidence indicates that long-term rents do tend to predict short term rents but they are underestimated. This indicates that market participants may be able to, at least partially, predict future declines in rents. These results imply that a rent index should hold constant not just location and property characteristics but also lease term and potentially other lease attributes.

This paper contributes to these lines of literature by developing a hedonic model of industrial rents in the Chicago metropolitan area, and controlling for a wide range of determinants including characteristics of the property, access to transportation infrastructure, neighborhood features, and the term structure of the lease agreement. The hedonic model is estimated over a recent time period, which includes large macroeconomic shocks to the economy and we develop a constant quality industrial rent index to track changes in rents over the business cycle. The remainder of the paper reviews the hedonic model, presents the data, introduces the empirical results, and provides a discussion of the results and conclusion.

Regional Science and Urban Economics, Vol 56 (January 2016): pg. 34-45. DOI. This article is @ Elsevier and permission has been granted for this version to appear in e-Publications@Marquette. Elsevier does not grant permission for this article to be further copied/distributed or hosted elsewhere without the express permission from Elsevier. 


\section{Empirical specification and data}

We estimate several semi-log hedonic models using an ordinary least squares model (OLS) and a spatial error model (SEM). The specification includes the attributes of the property, the location, and the lease,

$$
\ln (r)=\beta X+\gamma \quad(1)
$$

where $r$ is the $n \times 1$ vector of observations on the dependent variable (real rent per square foot per year), $\beta$ is the $k \times 1$ vector of regression parameters to be estimated empirically, $X$ is the $n \times k$ matrix of observation on $k$ explanatory variables, and $y$ is a $n \times 1$ vector of errors. The vector of explanatory variables $X$ consists of hedonic characteristics of the property (i.e., structural attributes such as building age, drive-ins, parking ratio, etc.), characteristics of the location of each building relative to transportation infrastructure (i.e., distance to the closest airport, rail line, water port, and intermodal points), lease attributes (i.e., the year when the lease is signed, lease type, use, occupancy, and lease purpose) and local neighborhood characteristics (i.e., distance to commuter rail stations, the fraction of the population that is nonwhite, median age, population density, and average household age).

Table 1 provides the summary statistics for the variables in the estimation data set. The data on the rental properties is collected from CoStar for the Chicago metropolitan area for leases signed to occupy space in industrial properties. For market participants, CoStar is one of the largest providers of commercial real estate information. CoStar's database contains more than 77 billion square feet of inventory, 1.5 million listings, and 10.6 million images of properties. The primary users of CoStar are commercial property brokers. CoStar collects the data by contacting property owners, brokers, and local government officials for information. Individuals can enter a listing into the system and CoStar independently verifies the listing. While not identical, CoStar resembles the single family market Multiple Listing Service

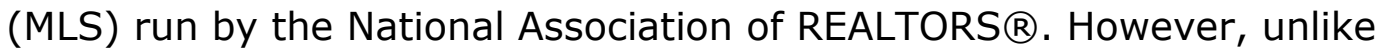
the MLS, CoStar is a for profit company listed on NASDAQ. CoStar

Regional Science and Urban Economics, Vol 56 (January 2016): pg. 34-45. DOI. This article is (C) Elsevier and permission has been granted for this version to appear in e-Publications@Marquette. Elsevier does not grant permission for this article to be further copied/distributed or hosted elsewhere without the express permission from Elsevier. 
NOT THE PUBLISHED VERSION; this is the author's final, peer-reviewed manuscript. The published version may be accessed by following the link in the citation at the bottom of the page.

does provide a unique view of the market place because it covers all property that is marketed, not just investment grade property.

Table 1. Summary statistics.

\begin{tabular}{|c|c|c|c|c|c|}
\hline Variable & Observation & Mean & $\begin{array}{l}\text { Standard } \\
\text { deviation }\end{array}$ & Min & Max \\
\hline \multicolumn{6}{|l|}{ Property } \\
\hline $\begin{array}{l}\text { Parking ratio (parking } \\
\text { spaces per } 1000 \text { square } \\
\text { feet of gross leasable } \\
\text { area) }\end{array}$ & 1735 & 1.46 & 1.04 & 0.01 & 10.00 \\
\hline $\begin{array}{l}\text { No. drive-ins/1000 square } \\
\text { feet }\end{array}$ & 2645 & 0.14 & 0.24 & 0.00 & 6.00 \\
\hline Year built & 2645 & $1,982.42$ & 19.98 & $1,860.00$ & $2,010.00$ \\
\hline Lease square feet & 2645 & $34,058.06$ & $71,316.97$ & 108.00 & $915,643.00$ \\
\hline $\begin{array}{l}\text { Distance to water port } \\
\text { (miles) }\end{array}$ & 2645 & 24.28 & 11.23 & 2.26 & 81.03 \\
\hline Distance to airport (miles) & 2645 & 11.49 & 10.20 & 0.00 & 76.76 \\
\hline $\begin{array}{l}\text { Distance small airport } \\
\text { (miles) }\end{array}$ & 2645 & 8.41 & 5.05 & 0.00 & 21.12 \\
\hline $\begin{array}{l}\text { Distance to railroad } \\
\text { (miles) }\end{array}$ & 2645 & 0.69 & 0.93 & 0.00 & 5.80 \\
\hline $\begin{array}{l}\text { Distance to interstate } \\
\text { highway (miles) }\end{array}$ & 2645 & 1.84 & 2.05 & 0.00 & 14.57 \\
\hline $\begin{array}{l}\text { Distance to intermodal } \\
\text { point (miles) }\end{array}$ & 2645 & 4.12 & 4.76 & 0.01 & 25.13 \\
\hline $\begin{array}{l}\text { Minimum ceiling height } \\
\text { (feet) }\end{array}$ & 2522 & 18.41 & 5.90 & 7.00 & 40.00 \\
\hline Cranes & 2645 & 0.04 & 0.19 & 0.00 & 1.00 \\
\hline Rail access & 2645 & 0.07 & 0.26 & 0.00 & 1.00 \\
\hline Owned by tenant & 2645 & 0.02 & 0.14 & 0.00 & 1.00 \\
\hline \multicolumn{6}{|l|}{ Lease } \\
\hline $\begin{array}{l}\text { Rent (real dollars per } \\
\text { square foot per year in } \\
2012-J u l y-D e c e m b e r \\
\text { dollars) }\end{array}$ & 2645 & 7.14 & 2.94 & 0.69 & 32.05 \\
\hline $\begin{array}{l}\text { Subleased (excluded } \\
\text { leased) }\end{array}$ & 2645 & 0.02 & 0.12 & 0.00 & 1.00 \\
\hline $\begin{array}{l}\text { Single tenant (excluded } \\
\text { multi-tenant) }\end{array}$ & 2645 & 0.11 & 0.31 & 0.00 & 1.00 \\
\hline Full service & 2645 & 0.16 & 0.37 & 0.00 & 1.00 \\
\hline $\begin{array}{l}\text { Modified gross (excluded } \\
\text { net) }\end{array}$ & 2645 & 0.42 & 0.49 & 0.00 & 1.00 \\
\hline Office & 2645 & 0.04 & 0.21 & 0.00 & 1.00 \\
\hline Flex & 2645 & 0.02 & 0.15 & 0.00 & 1.00 \\
\hline $\begin{array}{l}\text { Retail (excluded } \\
\text { warehouse) }\end{array}$ & 2645 & 0.01 & 0.11 & 0.00 & 1.00 \\
\hline Lease term (years) & 1442 & 4.09 & 2.73 & 0.19 & 25.02 \\
\hline Year leased signed & 2645 & $2,008.51$ & 2.36 & $2,003.00$ & $2,012.00$ \\
\hline \multicolumn{6}{|c|}{ Demographics and the local market } \\
\hline Nonwhite fraction ${ }^{a}$ & 2645 & 0.22 & 0.19 & 0.02 & 1.00 \\
\hline
\end{tabular}

Regional Science and Urban Economics, Vol 56 (January 2016): pg. 34-45. DOI. This article is @ Elsevier and permission has been granted for this version to appear in e-Publications@Marquette. Elsevier does not grant permission for this article to be further copied/distributed or hosted elsewhere without the express permission from Elsevier. 
NOT THE PUBLISHED VERSION; this is the author's final, peer-reviewed manuscript. The published version may be accessed by following the link in the citation at the bottom of the page.

$\begin{array}{llllll}\text { Variable } & \text { Observation } & \text { Mean } & \begin{array}{c}\text { Standard } \\ \text { deviation }\end{array} & \text { Min } & \text { Max } \\ \begin{array}{l}\text { Median age (10s of years) } \\ \text { a }\end{array} & 2645 & 3.48 & 0.47 & 2.01 & 6.41 \\ \begin{array}{l}\text { Density (population per } \\ \text { square mile in 10,000s) a }\end{array} & 2645 & 0.28 & 0.40 & 0.00 & 3.57 \\ \begin{array}{l}\text { Average household size } \\ \begin{array}{l}\text { Distance to commuter rail } \\ \text { (miles) }\end{array}\end{array} & 2645 & 2.81 & 0.38 & 1.56 & 4.21 \\ \begin{array}{l}\text { Distance to city center } \\ \text { (miles) }\end{array} & 2645 & 2.88 & 2.96 & 0.01 & 38.14 \\ \text { aLocal market data are collected from the } 2000 \text { Census at the census tract level. }\end{array}$

The average real rent in Chicago in July-December 2012 dollars is $\$ 7.14$ per square foot per year, with substantial variation as indicated by a standard deviation of $\$ 2.94$. Real rents are calculated by normalizing nominal rents by the urban Consumer Price Index excluding housing and are in second half of 2012 dollars per square foot. These are transaction rents (i.e., the rent paid in the first month at the time of the transaction) but they do not include additional perks used to entice tenants such as a first month free rent or free operating expenses. Therefore, the rents may be smoothed relative to effective rents and may miss the timing of any downturn in rents as landlords attempt to maintain published rents while reducing the actual rent through unpublished concessions. However, compared to asking rents we would expect these rents to be less smooth and to time the market more accurately (Webb and Fisher, 1996). The majority of tenants use the rented space for warehouse purposes. A small minority use the space for office, retail, or flex purposes, but these uses are being conducted in an industrial property, not in an office building or a retail building. This was confirmed by a visual inspection of property photos when the data was collected. The buildings are best described as generic boxes often found in industrial parks.

\subsection{Property attributes}

There are 2645 observed lease transactions. Unfortunately, some of the independent variables have missing data for some of the observations. To avoid having to drop these observations, when a variable has missing values we use a categorical approach. For example, 1735 of the 2645 leases report the parking ratio, defined as the number of parking spaces per 1000 square feet of gross leasable

Regional Science and Urban Economics, Vol 56 (January 2016): pg. 34-45. DOI. This article is @ Elsevier and permission has been granted for this version to appear in e-Publications@Marquette. Elsevier does not grant permission for this article to be further copied/distributed or hosted elsewhere without the express permission from Elsevier. 
area. For the 910 observations with missing values for parking ratio, we define a dummy variable equal to one; otherwise, the variable is zero. The non-missing observations categorize the property as having parking ratios in one of four categories (i.e., parking ratio $\leq 1$;

$1<$ parking ratio $\leq 1.5 ; 1.5<$ parking ratio $\leq 2$; and parking ratio $>2$ ). While there is no expected sign on the missing data dummy variables, it is anticipated that tenants are willing to pay more per square foot when it is associated with more parking. This is consistent with the findings of Cutter and DeWoody (2010), who show that onsite and nearby public parking can confer pricing premiums for commercial property. The ability of a delivery truck to "drive in" the building should also confer value. The number of drive-ins is normalized by thousands of leasable square feet of the property, No. drive-ins/(1000 square feet). Consistent with empirical evidence for office property ( Ryan, 2005, Eichholtz et al., 2010, Slade, 2000, Brounen and Jennen, 2009, Cutter and DeWoody, 2010, Wiley et al., 2010, Miller et al., 2008 and Munneke and Slade, 2000), we expect that more recently built or renovated industrial property, as measured by the variable year built, should have a higher rent. It is anticipated that larger leases, measured by lease square feet, will pay lower rents because of lower per square foot operating costs, simpler set up of the space, more tenant power in the lease negotiation process, often higher tenant credit quality, and perhaps the increased difficulty of leasing larger spaces. However, it is important to note that prior empirical evidence is mixed with some ( Ryan, 2005) finding the expected negative sign for industrial rents in some areas but not in others (i.e., the East County and Centre City markets in San Diego, although not for the South Bay area) and others (Jennen and Brounen, 2009 and Brounen and Jennen, 2009) finding a positive relationship for office property. The distance from the floor to the ceiling, measured by minimum ceiling height, can be a key amenity for efficiently storing goods in a warehouse. We expect that higher ceilings will command a higher rent. Indicators are also included for the existence of a crane (cranes) and access to rail (rail access). Both of these attributes should be associated with higher rent. The last property characteristic is whether the property is owned by the tenant (owned by tenant). This is included to proxy for any incentives a joint owner-renter has to pay rents above or below market rates. These

Regional Science and Urban Economics, Vol 56 (January 2016): pg. 34-45. DOI. This article is (c) Elsevier and permission has been granted for this version to appear in e-Publications@Marquette. Elsevier does not grant permission for this article to be further copied/distributed or hosted elsewhere without the express permission from Elsevier. 
incentives may include the desire to have sufficient returns from property ownership or perhaps tax incentives.

One of the key attributes of industrial property is access to major modes of transportation. In the Chicago area, this includes access to a large airport (i.e., O'Hare and Midway, and even Mitchell Field in Milwaukee for those in the northern regions of the Chicago Metropolitan area). We compute the distance of the property to ports on Lake Michigan to rail lines, to the interstate highway system, and to intermodal points where goods can be transferred from one mode of transportation to another (e.g., rail to air, rail to truck, or rail to port). ${ }^{5}$ The average distance to airport is almost 11.5 miles, and the average distance to water port is approximately 24 miles. We also include measures of distance to small or regional airports, distance to small airport. Industrial rental property is found to be most aggressively clustered around interstates and rail lines. The average distance to an interstate highway is just under 2 miles, and the average distance to rail is less than 1 mile. The average distance to intermodal point is 4.1 miles. We anticipate that being closer to transportation modes and intermodal points is valuable to industrial property users and should be associated with a real rent premium.

Fig. 1 reaffirms the importance of transportation infrastructure for industrial property. The dots indicate the location of the leases included in the estimation data set. The leases are clustered around O'Hare airport, with gray shading indicated an airport and along key highway and rail lines. Note that there are very few leases that are not near rail lines, highways, or an airport. Thus, the relative importance of the mode of transportation and the sensitivity of tenants to the availability of the various modes is an empirical question. 


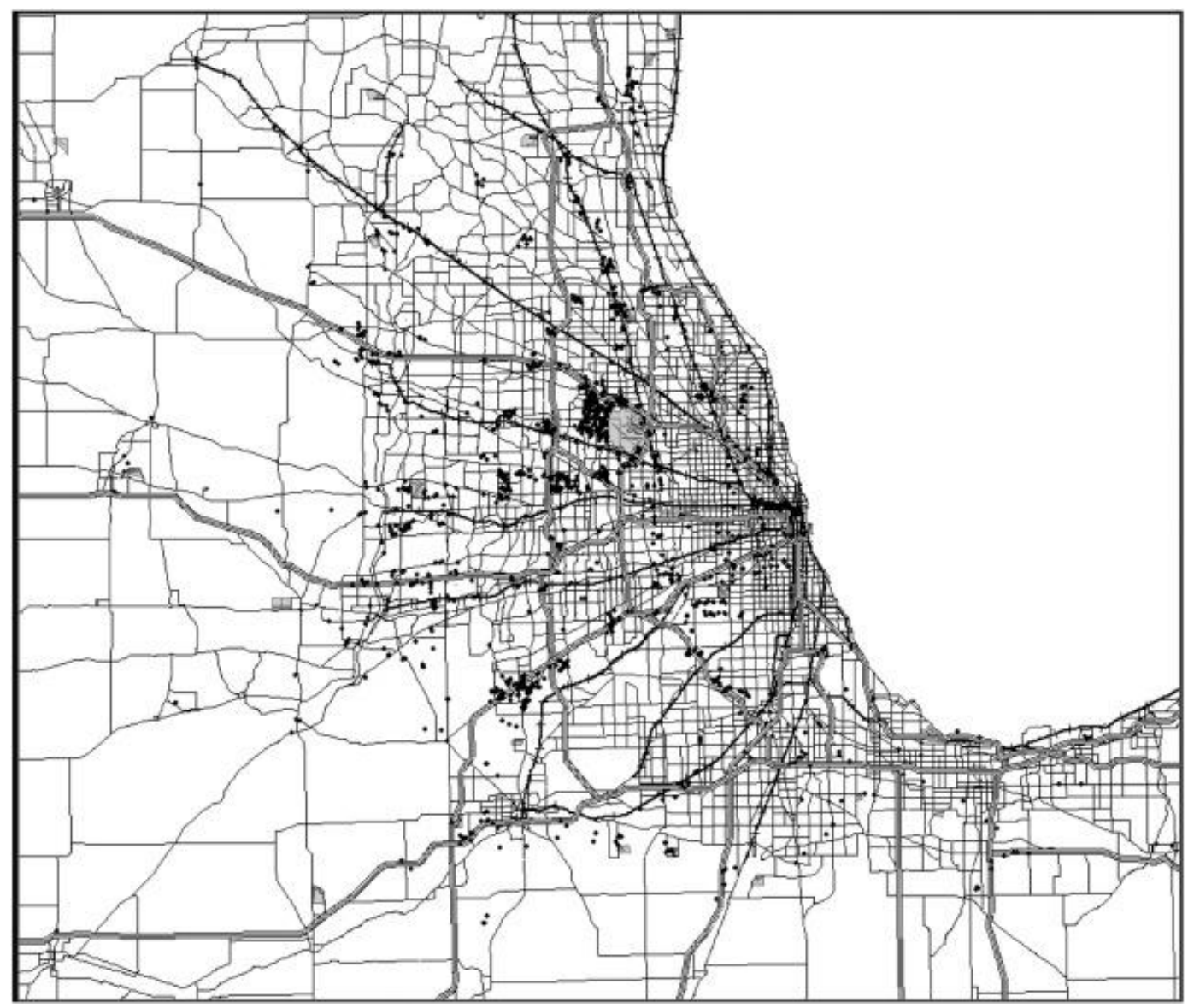

Fig. 1. Spatial distribution of leases in the Chicago metropolitan area: roads, rail, and airports.

Leases are indicated by dots. Rail lines are indicated by the lines with dashes. Airports are indicated by the grey areas. Interstate highways are indicated by the double lines and other major roads by the smaller less dense lines.

The empirical evidence on whether access to transportation infrastructure is capitalized into rents and prices is mixed. Fehribach et al. (1993) find evidence of this negative relationship between the distance to an airport and industrial property prices. Brounen and Jennen (2009) find an office rent premium associated with the proximity to train stations and lower rents nearer to a highway junction, and Ryan (2005) finds that being located near highway ramps or light rail transit stations is mostly insignificant for industrial property rents. Using state-level data, Cohen and Paul (2007) show that higher levels of public highway or airport infrastructure are capitalized into industrial property value for manufacturing firms, and Chegut et al. (2011) find mixed results for office leases. Finally, as noted earlier, Sivitanidou (1995) finds some indication of differential 
NOT THE PUBLISHED VERSION; this is the author's final, peer-reviewed manuscript. The published version may be accessed by following the link in the citation at the bottom of the page.

premiums in asking rents of access to transportation infrastructure for firms renting larger versus smaller spaces.

\subsection{Lease attributes}

How the space is occupied may also affect rents. Leases can be directly or indirectly leased from the original tenant (subleased). A small fraction (approximately $2 \%$ ) of our leases are subleased. The impact of this variable is an empirical question and potentially could vary over the business cycle. When only one tenant (single tenant) occupies the whole building, the landlord is subject to more tenant risk (i.e., risk of default by the tenant). If a tenant vacates, then all of the expected cash flow will be lost until a new tenant is found. Therefore, turnover risk is very high. This risk should drive single tenant rents up relative to multiple tenant lease buildings, and hence we would expect a positive sign on its coefficient.

Leases can also be categorized based on who pays the operating expenses of the property. In a full service lease, the landlord pays all the operating expenses (full service). In a modified gross lease, the tenant and landlord share the operating expenses (modified gross). While the mechanism of the sharing can take a myriad of forms, a common structure is for the landlord to cover the expenses up to a certain value, with the tenant paying for all additional expenses. This is often called an expense stop and is frequently set to the expenses in the year before the lease is signed. The last type of lease is called a net lease. In a net lease, the tenant typically pays all the operating expenses except the management fee (net). There are again many variations where certain expenses are treated as net, such as utilities, and other types of expenses are treated as gross, such as garbage and cleaning common areas. In general, we should expect that rent on leases should be highest for full service, next highest for modified gross, and lowest for net. For example, Eichholtz et al. (2010) find that gross office rents are $4 \%$ higher than those quoted net of utilities.

The use of the property may also affect the rent. For example, if office space has a higher turnover cost, then these costs should be capitalized into the rent. One component of turnover cost is the extent to which the landlord must improve or adjust the space to meet the needs of the tenant. These costs are likely highest for retail (retail)

Regional Science and Urban Economics, Vol 56 (January 2016): pg. 34-45. DOI. This article is @ Elsevier and permission has been granted for this version to appear in e-Publications@Marquette. Elsevier does not grant permission for this article to be further copied/distributed or hosted elsewhere without the express permission from Elsevier. 
and office (office) space because they require meeting spaces, hallways, offices, and cubicles. In contrast, warehouse space requires very little additional infrastructure provided by the landlord. In practice, the extent to which the landlord covers tenant improvement costs is a negotiating point; typically, the landlord provides a tenant an improvement allowance which will only cover some of the costs. Overall, we expect that warehouse space use pays the lowest rent due to lower turnover costs and the need for fewer amenities and tenant improvements.

The last attribute of the lease is how long it lasts (lease term). Leases in the industrial property market can be very short or very long. The average lease term is just over 4 years, and the longest in the data is approximately 25 years. Under the pure expectations hypothesis, long-term leases reflect the geometric mean of all future short term leases. However, longer term leases have lower turnover risk for the landlord but more releasing risk for the tenant. In addition, the credit quality of the tenant has substantial impacts in term structure. The empirical evidence is that longer term leases tend to have higher rental rates but some of the evidence is mixed (Ambrose and Yildirim, 2008, Bond et al., 2008, Clapham and Gunnelin, 2003, Englund et al., 2004, Englund et al., 2008 and Gunnelin and Soderberg, 2003).

\subsection{Demographics and local neighborhood features}

A warehouse also needs to attract a workforce and numerous authors (Timothy and Wheaton, 2001, McMillan and Singell, 1992 and Eberts, 1981) find the existence of positively sloped intracity wage gradients. Sivitanidou (1995) focuses on the role of spatial amenities including worker related amenities. Thus, there is a balance between locating industrial firms close enough to their workforce such that wages can be kept relatively low, but far enough away so that non-productive amenities (e.g., absence of noise, traffic, etc.) that are important to households are not also capitalized into the industrial rents. To proxy for potential local amenities and location preferences we include demographic measures at the census tract level from the 2000 Census. These include the density of the population (density), the median age of the population (median age), the average size of

Regional Science and Urban Economics, Vol 56 (January 2016): pg. 34-45. DOI. This article is (C) Elsevier and permission has been granted for this version to appear in e-Publications@Marquette. Elsevier does not grant permission for this article to be further copied/distributed or hosted elsewhere without the express permission from Elsevier. 
households (average household size), and the fraction of the population that is not white (nonwhite fraction). In addition, it should be easier to attract workers when the building is close to a commuter transit terminal. To measure this worker amenity, we include the distance in miles to the nearest commuter transit terminal (distance to commuter rail). The average distance is 2.9 miles, although there is considerable variability with the standard deviation exceeding the mean. To control for access to downtown the distance to city center measured in miles is also included. The average of distance to city center is 23.3 miles, suggesting that most warehousing is located well outside the higher land cost areas of the city. If warehouses are willing to pay premiums for being close to their desired workforce (i.e., locations the workforce cares about), they must outbid other potential uses for the land and pay higher industrial rents. ${ }^{6}$

\subsection{Distributions of some key attributes}

Table 2, Table 3 and Table 4 provide the distribution of a few key attributes. Table 2 shows the average rent per square foot (psf) in nominal and real terms for each year that the lease is signed. The data are very sparse in the early years of the sample, but there are over 100 transactions reported in 2003 and earlier. The peak year, in terms of transactions observed, is 2010 where 453 leases were recorded. The 226 observed transactions in 2012 include leases signed up to November 1 st of that year. The distribution of rents is also very wide. Table 3 reports the number of leases per value in 2 dollar increments. The most prevalent category is 6 to 8 dollars psf in both nominal and real terms. The distribution of the lease size measured in square feet is skewed left as shown in Table 4, indicating a large group of small leases and a modest group of tenants with very large leases. This may reflect the use of the space and the type of industry in which the company is involved.

Table 2. Rents by signing date.

$\begin{array}{llcccc}\text { Year } & \begin{array}{c}\text { Number of } \\ \text { leases }\end{array} & \begin{array}{c}\text { Average } \\ \text { nominal } \\ \text { price }\end{array} & \begin{array}{c}\text { Standard } \\ \text { deviation } \\ \text { nominal price }\end{array} & \begin{array}{c}\text { Average real } \\ \text { rent (2012 } \\ \text { dollars) }\end{array} & \begin{array}{c}\text { Standard } \\ \text { deviation real rent } \\ \text { (2012 dollars) }\end{array} \\ \begin{array}{l}\text { 2003\& } \\ \text { earlier }\end{array} & 124 & 5.96 & 2.19 & 7.58 & 2.78 \\ \mathbf{2 0 0 4} & 91 & 6.10 & 2.17 & 7.55 & 2.68\end{array}$

Regional Science and Urban Economics, Vol 56 (January 2016): pg. 34-45. DOI. This article is ( Elsevier and permission has been granted for this version to appear in e-Publications@Marquette. Elsevier does not grant permission for this article to be further copied/distributed or hosted elsewhere without the express permission from Elsevier. 
NOT THE PUBLISHED VERSION; this is the author's final, peer-reviewed manuscript. The published version may be accessed by following the link in the citation at the bottom of the page.

$\begin{array}{llllll}\text { Year } & \begin{array}{c}\text { Number of } \\ \text { leases }\end{array} & \begin{array}{c}\text { Average } \\ \text { nominal } \\ \text { price }\end{array} & \begin{array}{c}\text { Standard } \\ \text { deviation } \\ \text { nominal price }\end{array} & \begin{array}{c}\text { Average real } \\ \text { rent (2012 } \\ \text { dollars) }\end{array} & \begin{array}{c}\text { Standard } \\ \text { deviation real rent } \\ \text { (2012 dollars) }\end{array} \\ \mathbf{2 0 0 5} & 99 & 6.00 & 2.20 & 7.19 & 2.63 \\ \mathbf{2 0 0 6} & 151 & 6.42 & 1.93 & 7.45 & 2.24 \\ \mathbf{2 0 0 7} & 352 & 7.00 & 2.46 & 7.89 & 2.77 \\ \mathbf{2 0 0 8} & 369 & 6.86 & 2.61 & 7.45 & 2.83 \\ \mathbf{2 0 0 9} & 438 & 6.64 & 2.74 & 7.23 & 2.99 \\ \mathbf{2 0 1 0} & 453 & 6.51 & 3.03 & 6.98 & 3.25 \\ \mathbf{2 0 1 1} & 342 & 6.21 & 2.91 & 6.45 & 3.03 \\ \mathbf{2 0 1 2} & 226 & 5.93 & 2.68 & 6.03 & 1.71 \\ \text { All } & 2645 & 6.49 & 2.68 & 7.14 & 2.94\end{array}$

Rent is nominal or real second half of 2012 dollars per square foot per year.

Table 3. Description of nominal and real rental rates.

\begin{tabular}{llllll} 
& \multicolumn{2}{c}{ Distribution of nominal rents } & & \multicolumn{2}{c}{ Distribution of real rents } \\
\cline { 2 - 3 } Rent (\$ psf/year) & $\begin{array}{c}\text { Number of } \\
\text { leases }\end{array}$ & $\begin{array}{c}\text { Percentage of } \\
\text { leases }\end{array}$ & & $\begin{array}{c}\text { Number of } \\
\text { leases }\end{array}$ & $\begin{array}{c}\text { Percentage of } \\
\text { leases }\end{array}$ \\
Rent $\leq \mathbf{2}$ & 28 & 1 & 21 & 1 & 10 \\
$\mathbf{2}<$ Rent $\leq \mathbf{4}$ & 398 & 15 & 257 & 26 \\
$\mathbf{4}<$ Rent $\leq \mathbf{6}$ & 804 & 30 & 687 & 29 \\
$\mathbf{6}<$ Rent $\leq \mathbf{8}$ & 916 & 35 & 775 & 23 \\
$\mathbf{8}<$ Rent $\leq \mathbf{1 0}$ & 322 & 12 & 600 & 7 \\
$\mathbf{1 0}<$ Rent $\leq \mathbf{1 2}$ & 104 & 4 & 173 & 3 \\
$\mathbf{1 2}<$ Rent $\leq \mathbf{1 4}$ & 29 & 1 & 79 & 1 \\
$\mathbf{1 4}<$ Rent $\leq \mathbf{1 6}$ & 23 & 1 & 20 & 0 \\
$\mathbf{1 6}<$ Rent $\leq \mathbf{1 8}$ & 8 & 0 & 11 & 1 \\
$\mathbf{1 8}<$ Rent & 13 & 0 & 22 & 100
\end{tabular}

Rent is dollars (nominal or 2012 real) per square foot per year.

Table 4. Lease square feet.

\begin{tabular}{|c|c|c|}
\hline Square feet of lease & Number of leases & Percentage of leases \\
\hline Square feet $\leq 5,000$ & 974 & 37 \\
\hline $5,000<$ Square feet $\leq 10,000$ & 458 & 17 \\
\hline $10,000<$ Square feet $\leq 20,000$ & 366 & 14 \\
\hline $20,000<$ Square feet $\leq 30,000$ & 185 & 7 \\
\hline $30,000<$ Square feet $\leq 40,000$ & 117 & 4 \\
\hline $40,000<$ Square feet $\leq 50,000$ & 90 & 3 \\
\hline $50,000<$ Square feet $\leq 60,000$ & 72 & 3 \\
\hline $60,000<$ Square feet $\leq 70,000$ & 45 & 2 \\
\hline $70,000<$ Square feet $\leq 80,000$ & 35 & 1 \\
\hline $80,000<$ Square feet $\leq 90,000$ & 21 & 1 \\
\hline $90,000<$ Square feet $\leq 100,000$ & 28 & 1 \\
\hline $100,000<$ Square feet $\leq 110,000$ & 34 & 1 \\
\hline
\end{tabular}

Regional Science and Urban Economics, Vol 56 (January 2016): pg. 34-45. DOI. This article is @ Elsevier and permission has been granted for this version to appear in e-Publications@Marquette. Elsevier does not grant permission for this article to be further copied/distributed or hosted elsewhere without the express permission from Elsevier. 
NOT THE PUBLISHED VERSION; this is the author's final, peer-reviewed manuscript. The published version may be accessed by following the link in the citation at the bottom of the page.

Square feet of lease

$110,000<$ Square feet $\leq 120,000$

$120,000<$ Square feet $\leq 130,000$

$130,000<$ Square feet $\leq 140,000$

$140,000<$ Square feet $\leq 150,000$

$150,000<$ Square feet

All leases

The square feet of the lease signed.

\begin{tabular}{ll}
\multicolumn{1}{c}{ Number of leases } & \multicolumn{1}{c}{ Percentage of leases } \\
24 & 1 \\
25 & 1 \\
22 & 1 \\
14 & 1 \\
135 & 5 \\
2,645 & 100
\end{tabular}

\section{Empirical results}

Table $5 \mathrm{a}$ and Table $5 \mathrm{~b}$ report the regression model findings. We present findings from a simple OLS model that allows errors to be correlated and clustered within markets areas. In the Appendix, we present a spatial error model (SEM). ${ }^{7}$ Since the SEM and OLS results are very similar, we report in the body of the text and all future specification tests using the OLS estimation approach. ${ }^{8}$ The explanatory variables are broken down into property attributes, lease attributes, time period dummies, and local neighborhood characteristics. The explanatory power of the regression is reasonable with adjusted $R^{2}=0.54$. Market areas were defined by CoStar. The appendix provides a brief description of the market areas. These areas will be used to cluster the errors and for fixed effects. The results, as shown in Table $5 a$ and Table 5b, mostly meet expectations in terms of sign, and many of the coefficients are statistically significant at the $10 \%$ level or better. The market area fixed effects are reported in the Appendix A. The first column represents result without market area fixed effects and the second column the results with fixed effects. Fixed effects is the preferred specification because it controls for any unobserved time invariant characteristics associated with each market. This could relate to building standards, road, or other infrastructure quality and overall desirability of the market. The results are therefore identified by variation across buildings, leases, and time within each market.

Table 5a. Results-Part 1.

\begin{tabular}{|c|c|c|c|c|c|}
\hline \multirow[b]{2}{*}{ Category } & \multirow[b]{2}{*}{ Variable } & \multicolumn{2}{|c|}{ Basic } & \multicolumn{2}{|c|}{ Fixed effects } \\
\hline & & Coefficient & t-statistics & Coefficient & $t$-statistics \\
\hline & Intercept & $-3.032 * *$ & -2.73 & $-2.750 * * *$ & -3.20 \\
\hline Property & Parking ratio $=$. & $-0.053 * *$ & -2.42 & $-0.038^{*}$ & -1.80 \\
\hline
\end{tabular}

Regional Science and Urban Economics, Vol 56 (January 2016): pg. 34-45. DOI. This article is @ Elsevier and permission has been granted for this version to appear in e-Publications@Marquette. Elsevier does not grant permission for this article to be further copied/distributed or hosted elsewhere without the express permission from Elsevier. 
NOT THE PUBLISHED VERSION; this is the author's final, peer-reviewed manuscript. The published version may be accessed by following the link in the citation at the bottom of the page.

Basic

Category

(excluded: park Parking ratio $\leq 1.0$ ratio > 2) ceiling $\leq 12$ )

(excluded: no cranes)

(excluded: no Rail rail) (excluded: not owned)

$$
\begin{aligned}
& 1.0<\text { Parking } \\
& \text { ratio } \leq 1.5 \\
& 1.5<\text { Parking } \\
& \text { ratio } \leq 2.0
\end{aligned}
$$

Owned

\section{Market fixed effects}

Summary Stats
Log(dist to water port)

Log(dist to airport)

Log(dist to small airport)

Log(dist to rail)

Log(dist to interstate)

Log(dist to intermodal) 0.019

\subsection{6}

0.062

0.032

$0.082 *$

0.051

$$
-0.093 * *
$$

0.025

$-0.073^{* *}$

1.23

$0.176 * * *$

5.24

1.04
1.67

0.94

1.82

0.99

$-2.21$

$-0.048$

$-0.21$

$-0.025^{* * *}-3.36$

$$
-0.003
$$

$-0.23$

$-0.002-0.20$

$-0.31$

1.65

\section{Fixed effects}

Coefficient $\boldsymbol{t}$-statistics

$-0.102 * * *-4.68$

$-0.064 * * *-3.42$

$-0.010-0.38$

$0.112 * \quad 1.75$

$0.004 * * * \quad 7.88$

$-0.148 * * *-12.67$

$0.049 \quad 1.06$

$0.017 \quad 0.52$

0.056* $\quad 1.87$

$0.036 \quad 1.20$

$0.072 * * \quad 2.09$

$0.043 \quad 0.87$

$-0.073-1.65$

$0.041 * \quad 1.85$

$-0.014 \quad-0.47$

$0.188 * * * \quad 6.64$

$-0.470 * * *-2.84$

$0.000-0.02$

$0.001 \quad 0.21$

$-0.004-0.59$

$-0.003-0.48$

$0.007 \quad 1.11$

$\mathrm{x}$

2645

0.589

Dependent variable: log(real rent per square foot per year, deflated by CPI-U). The standard errors for the Standard errors are robust and clustered by market. Part 1 and Part 2 are estimated in one regression and reported in two tables to improve readability only. There are 28 markets defined by CoStar. Boone County is the excluded market. Fixed effects estimates are provided in the Appendix.

*Coefficient is significant at the $10 \%$ level in a $t$-tailed test.

$* *$ Coefficient is significant at the $5 \%$ level in a $t$-tailed test.

$* * *$ Coefficient is significant at the $1 \%$ level in a $t$-tailed test. 
NOT THE PUBLISHED VERSION; this is the author's final, peer-reviewed manuscript. The published version may be accessed by following the link in the citation at the bottom of the page.

Table 5b. Results-Part 2.

Category

Lease (excluded: direct leased)

(excluded: multitenant)

(excluded: net)

(excluded: warehouse)

(excluded: lease term $<1$ year)

\section{Time}

(excluded:

year $=2012-2$ )
Variable

Subleased

Single tenant

Full service

Modified gross

Office

Flex

Retail

Lease term $=$.

Lease

term $<2$ years

Lease

term $<3$ years

Lease

term $<4$ years

Lease

term $<5$ years

Lease

term $<10$ years

Lease

term $\geq 10$ years

Year $\leq 2003$

Year $=2004$

Year $=2005$

Year $=2006$

Year $=2007-1$

Year $=2007-2$

Year $=2008-1$

Year $=2008-2$

Year $=2009-1$

Year $=2009-2$

Year $=2010-1$

Year $=2010-2$

Year $=2011-1$

Year $=2011-2$

Year $=2012-1$

Nonwhite

Median age

Density

Household size

Log(dist to commuter rail)
Basic

Fixed effects

Coefficient $\begin{gathered}t- \\ \text { statistics }\end{gathered}$ Coefficient $\begin{gathered}t \text { - } \\ \text { statistics }\end{gathered}$

$-0.081^{*}-1.78$

$\begin{array}{llll}0.057 * * * & 2.93 & 0.053 * * & 2.38\end{array}$

$\begin{array}{llll}0.082 * * * & 3.34 & 0.081 * * * & 3.38\end{array}$

$\begin{array}{llll}0.066 * * * & 2.76 & 0.067 * * * & 2.90\end{array}$

$\begin{array}{llll}0.284 * * * & 7.82 & 0.274 * * * & 8.21\end{array}$

$\begin{array}{llll}0.027 & 0.87 & 0.030 & 1.09\end{array}$

$\begin{array}{llll}0.155 * * & 2.66 & 0.152 * * & 2.45\end{array}$

$\begin{array}{llll}0.050 * & 1.71 & 0.038 & 1.17\end{array}$

$\begin{array}{llll}-0.003 & -0.11 & -0.015 & -0.49\end{array}$

$\begin{array}{llll}-0.010 & -0.35 & -0.020 & -0.64\end{array}$

$\begin{array}{llll}0.041 & 1.31 & 0.021 & 0.67\end{array}$

$\begin{array}{llll}0.026 & 0.88 & 0.023 & 0.82\end{array}$

$\begin{array}{llll}0.048 & 1.41 & 0.037 & 1.04\end{array}$

$\begin{array}{llll}0.161 * * * & 3.88 & 0.147 * * * & 3.39\end{array}$

$\begin{array}{llll}0.304 * * * & 6.61 & 0.283 * * * & 6.75\end{array}$

$\begin{array}{llll}0.266 * * * & 4.85 & 0.232 * * * & 5.52\end{array}$

$\begin{array}{llll}0.238 * * * & 6.74 & 0.242 * * * & 7.27\end{array}$

$\begin{array}{llll}0.244 * * * & 5.81 & 0.244 * * * & 5.97\end{array}$

$\begin{array}{llll}0.240 * * * & 6.35 & 0.237 * * * & 5.73\end{array}$

$\begin{array}{llll}0.223 * * * & 6.04 & 0.216 * * * & 5.87\end{array}$

$\begin{array}{llll}0.194 * * * & 5.15 & 0.195 * * * & 5.24\end{array}$

$\begin{array}{llll}0.208 * * * & 4.88 & 0.187 * * * & 5.05\end{array}$

$0.174 * * * \quad 3.91 \quad 0.159 * * * \quad 3.95$

$0.113 * * \quad 2.58 \quad 0.096 * * \quad 2.42$

0.084* $2.03 \quad 0.075^{*} \quad 1.90$

$\begin{array}{llll}0.067 & 1.57 & 0.065 & 1.54\end{array}$

$\begin{array}{llll}-0.020 & -0.66 & -0.032 & -1.09\end{array}$

$\begin{array}{llll}0.020 & 0.56 & 0.019 & 0.54\end{array}$

$\begin{array}{llll}-0.009 & -0.30 & -0.013 & -0.52\end{array}$

$-0.197 * * *-2.91-0.192 * * *-3.12$

$\begin{array}{llll}-0.002 & -1.18-0.004 * * & -2.30\end{array}$

$\begin{array}{llll}-0.062 * * & -2.08-0.074 * * * & -2.78\end{array}$

$\begin{array}{llll}-0.113 * * * & -5.32 & -0.091 * * * & -3.97\end{array}$

$-0.028 * *-2.23-0.032 * *-2.32$

Regional Science and Urban Economics, Vol 56 (January 2016): pg. 34-45. DOI. This article is @ Elsevier and permission has been granted for this version to appear in e-Publications@Marquette. Elsevier does not grant permission for this article to be further copied/distributed or hosted elsewhere without the express permission from Elsevier. 
NOT THE PUBLISHED VERSION; this is the author's final, peer-reviewed manuscript. The published version may be accessed by following the link in the citation at the bottom of the page.

\begin{tabular}{|c|c|c|c|c|c|}
\hline \multirow[b]{2}{*}{ Category } & \multirow[b]{2}{*}{ Variable } & \multicolumn{2}{|c|}{ Basic } & \multicolumn{2}{|c|}{ Fixed effects } \\
\hline & & Coefficient & $\begin{array}{c}t- \\
\text { statistics }\end{array}$ & Coefficient & $\begin{array}{c}t- \\
\text { statistics }\end{array}$ \\
\hline & $\begin{array}{l}\text { Log(dist to city } \\
\text { center) }\end{array}$ & -0.097 & -0.52 & $0.263 * *$ & 2.06 \\
\hline
\end{tabular}

Dependent variable: $\log$ (real rent per square foot per year, deflated by CPI-U). The standard errors for the OLS model are robust and clustered by market. Part 1 and Part 2 are estimated in one regression and reported in two tables to improve readability only.

*Coefficient is significant at the $10 \%$ level in a $t$-tailed test.

$* *$ Coefficient is significant at the $5 \%$ level in a $t$-tailed test.

$* * *$ Coefficient is significant at the $1 \%$ level in a $t$-tailed test.

\subsection{Property attributes}

The ratio of parking spaces per 1000 square feet of leasable space, parking ratio, is an important part of an industrial property's characteristics. As noted above, since many of the spaces did not report the parking ratio, this variable is specified using a series of dummy variables with leases in properties with parking ratios greater than 2 being the excluded category. The results show that having less than one parking space per 1000 square feet of leasable space reduces the rent by approximately $10 \%$ as compared to the excluded category. This discount shrinks as the parking ratio increases and is statistically insignificant for the 1.5 to 2 category. The ability of trucks to drive into the property also imparts a rent premium. A one standard deviation increase (0.24) in the number of drive-ins per thousands of leasable square feet increases rent by $2.64 \%$. The age of the property, year built, also has the expected sign and is statistically significant.

Buildings that have been built more recently command higher rent. Each ten years is worth approximately a $4 \%$ premium. ${ }^{9}$ Bigger leases are associated with lower rents, with the point estimate showing that a $10 \%$ increase in square footage decreases rents by approximately $1.5 \%$. The ceiling height coefficients are of the expected sign and are statistically significant at the $10 \%$ level or better for two of the six categories. However, there is no evidence of a linear monotonic relationship between height and real rents. The existence of rail and a crane on the property is statistically insignificant. Property that is owned and rented by the same entity tends to pay substantial rent premiums (i.e., $18.8 \%$ higher). Lastly, despite the obvious clustering of the industrial properties around airports, highways, and rail

Regional Science and Urban Economics, Vol 56 (January 2016): pg. 34-45. DOI. This article is (C) Elsevier and permission has been granted for this version to appear in e-Publications@Marquette. Elsevier does not grant permission for this article to be further copied/distributed or hosted elsewhere without the express permission from Elsevier. 
infrastructure, nearly all of the coefficients on the distance variables are insignificant. Since distance measures are in log form, the coefficients are interpreted as elasticities. The distance to airports is negative and significant only when market fixed effects are not included, but even then the magnitude of the coefficient is very small. The coefficient for the distance for water ports is significant once fixed effects are included but given the sparsity of warehouses locating near water ports this result likely reflect other unobserved factors. We explore the transportation effects in more detail later in the paper.

\subsection{Lease attributes}

Table $5 b$ reports the results for the lease attributes, the year dummy variables, and the local neighborhood features. Leases where the tenant pays the operating expenses pay the lowest rent. When the landlord pays for the operating expenses, tenants pay approximately an $8.1 \%$ rent premium, and leases where the landlord and tenant have an expense sharing arrangement pay a smaller premium of approximately $7 \%$. As expected, single tenants pay a premium (i.e., $5 \%$ ) and subleased space pays a discount but the latter coefficient is only barely statistically significant.

The use of the space has substantial impacts on rents. For example, office space use pays a premium over warehouse space use of just over $27 \%$ and retail use pays a premium of $15 \%$. The results also provide some limited support for a term structure for leases. However, there is only evidence of a term related rent premium when the term is 10 years or longer, with a $15 \%$ premium. The shape of the term structure will be examined in more detail in a following section.

\subsection{Local neighborhood characteristics}

Tenants located in neighborhoods with more nonwhite households, more dense populations, larger households, and those further from public transportation all pay less in real rents. Specifically, a $10 \%$ increase in the nonwhite population reduces rents $1.9 \%$, whereas an additional 1000 persons per square mile in the census tract lowers rents approximately $0.7 \%$. An additional one-half person per household (note this is more than a one standard deviation

Regional Science and Urban Economics, Vol 56 (January 2016): pg. 34-45. DOI. This article is (C) Elsevier and permission has been granted for this version to appear in e-Publications@Marquette. Elsevier does not grant permission for this article to be further copied/distributed or hosted elsewhere without the express permission from Elsevier. 
change) reduces rents $4.5 \%$, whereas a doubling of the distance to a commuter rail station reduces rents by over $6 \%$. Interestingly, these results are similar to those found in a study of single-family residential home values in Chicago in 1999 by Immergluck and Smith (2006). They find negative impacts of minority population and a negative (albeit steeper) distance gradient for public transportation. In contrast to our findings, they actually find a positive impact of population density on residential sale prices after controlling for other neighborhood attributes. Presumably, the amenity effects that are likely proxied by density outweigh the congestion effects for residential, but not industrial properties.

\subsection{Time period dummies and a constant quality rent index}

The year dummy variables can provide an estimate of how rents have increased or decreased over time after controlling for all the attributes in the estimation. With a reasonably specified model, the results can be interpreted as constant quality and lease type rents. Not surprisingly, the results indicate that constant quality real rents have taken a dramatic drop from their peak in 2006.

Fig. 2 illustrates the results. Three measures of real rents are presented for the Chicago metropolitan area. Each of the rents is normalized to one in 2006. The first index (asking) is the average asking rents for warehouses reported by Cushman and Wakefield, which is the most easily obtained type of market information. It is published quarterly and is widely used by market participants. The data begin in 2006. Asking rents rise by $1 \%$ by the first half of 2008 and then drop by a little more than $20 \%$ through the end of 2012 . The asking rents also appear smoother (less volatile) than the other measures. The second index (transactions) is the average rent on the transactions used in the estimation. It peaks in 2007 and rose over $5 \%$ from the benchmark 2006 level. However, through the first half of 2009 the transactions index shows no sign of a consistent decline. By the end of 2012 however, it declines by over 30\% from peak. The third index (constant quality) is the estimated results from the fixed effects specification of the hedonic model reported in Table $5 a$ and Table $5 b$. This index is calculated by holding all continuous variables at their

Regional Science and Urban Economics, Vol 56 (January 2016): pg. 34-45. DOI. This article is (c) Elsevier and permission has been granted for this version to appear in e-Publications@Marquette. Elsevier does not grant permission for this article to be further copied/distributed or hosted elsewhere without the express permission from Elsevier. 
mean, for Boone County (i.e., one of the submarkets identified by CoStar), and all categorical variables at the category indicated by its mean value. The constant quality index shows almost no run up in real rents from 2004 through 2006 and a decline of rents by over 5\% by the end of 2008. The timing of the market cycle is substantially different for the constant quality rent index and it leads the raw transactions rents and asking rents. From the peak, the constant quality index drops to a low in the first half of 2011 that is almost 25\% lower than the peak. The other indexes do not show the drop during the summer of 2011, which is likely associated with the first debt ceiling crisis as the recovery stalled. The constant quality index also shows that rents may have started to flatten out in 2012. In contrast, the asking rents and the transactions rents have continued or even increased their pace of decline during 2012. Again, this is evidence that typical rent indexes miss the turning points of the market and provide faulty market signals to market participants at critical points in the market cycle. ${ }^{10}$

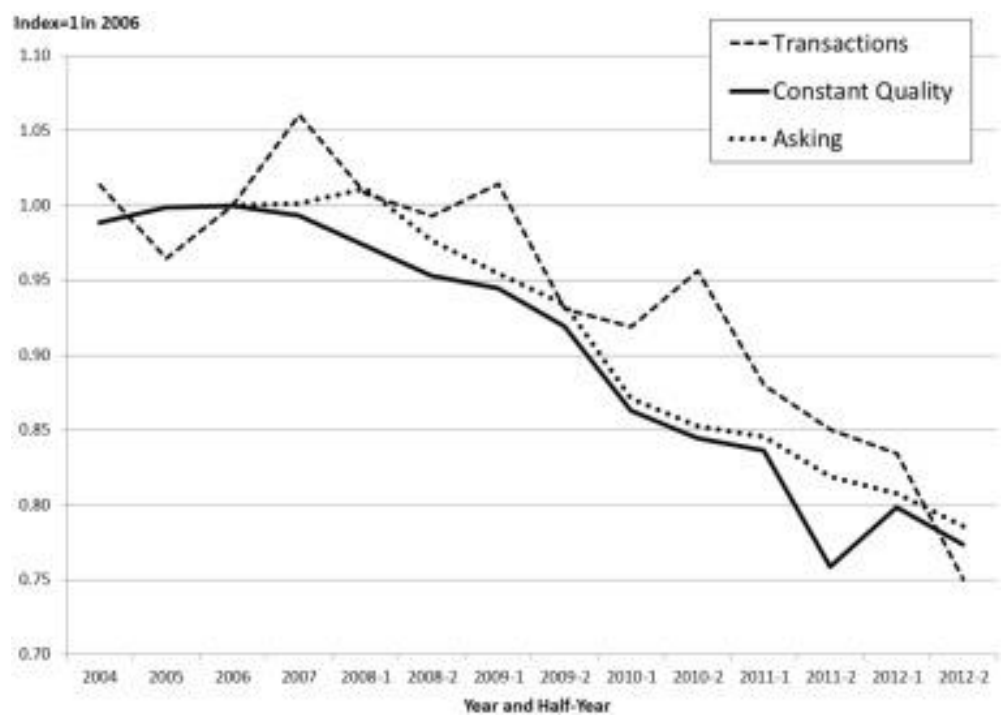

Fig. 2. Three measures of real rents.

Rents are expressed as dollars per square foot per year. All rents are normalized to 1 2006 because this is the year that the estimation data has an ample number of observations. Constant quality is the predicted real rent in each time period holding all continuous variables at their means. Categorical variables are set to 1 for the category where the mean value exists. The market is set to CoStar's submarket 1 , which is Boone County. Transactions is the average of the observed real rent transactions in each time period used in the estimation data set. Asking is the Cushman and Wakefield average real net rate for warehouse industrial property. The data were 
NOT THE PUBLISHED VERSION; this is the author's final, peer-reviewed manuscript. The published version may be accessed by following the link in the citation at the bottom of the page.

downloaded from www.cushwake.com "Market Beat Chicago Industrial Report," which is published quarterly-for most quarters.

Fig. 3 plots the constant quality real rent index, the Chicago industrial property vacancy rate reported by Costar, and the effective rent calculated by multiplying the constant quality real rental rate by the occupancy rate for Chicago. The rents are indexed to 1 in 2006. The figure shows a clear inverse relationship between vacancy and rents with well synchronized turning points. The effective rent proxy shows, as compared to the constant quality index, a larger and faster drop in rents. However, in proportional terms, the impact of vacancy is small compared to the drop in the rent on occupied space.

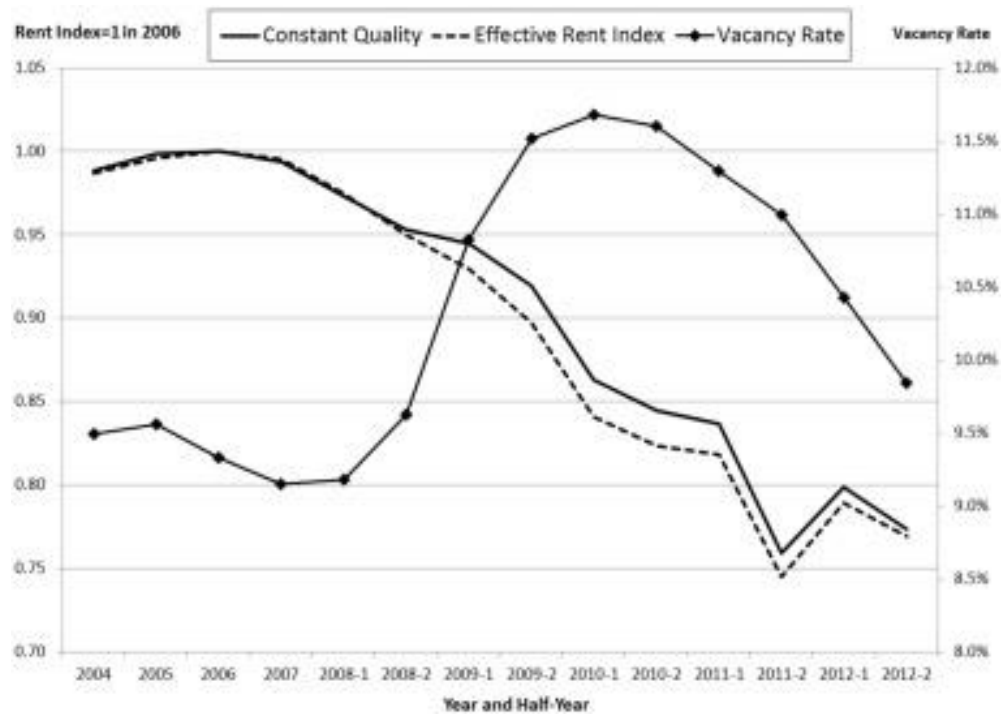

Fig. 3. Constant quality real effective rents and vacancy rates.

Rents are expressed as dollars per square foot per year. All rents are normalized to 1 2006 because this is the year that the estimation data has an ample number of observations. Constant quality is the predicted real rent in each time period holding all continuous variables at their means. Categorical variables are set to 1 for the category where the mean value exists. The market is set to CoStar's submarket 1 , which is Boone County. The vacancy rate is the CoStar reported vacancy rate for the metropolitan area. Effective rent is the estimated by multiplying the constant quality rent by the vacancy rate. 
NOT THE PUBLISHED VERSION; this is the author's final, peer-reviewed manuscript. The published version may be accessed by following the link in the citation at the bottom of the page.

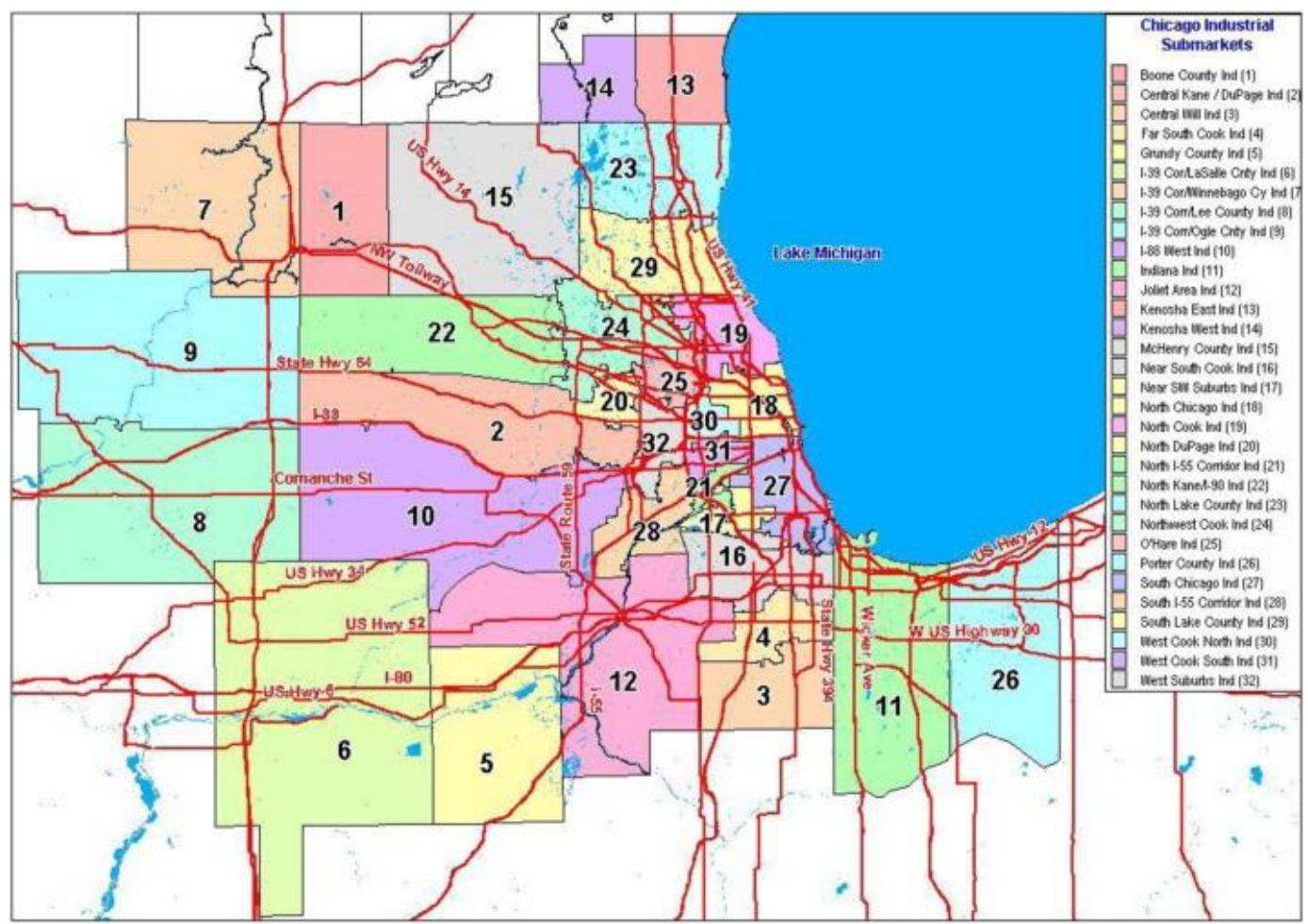

Fig. A1. CoStar submarket areas.

Chicago industrial submarket overview, CoStar Group, Copyright 1997-2006. These market numbers do not match those used for the fixed effects reported in the results. Some markets are combined for estimation purposes (preserving within market area variation of explanatory variables).

In summary, the constant quality index provides a substantially different view of market rents than simple averages calculated from reported transactions or asking rents. It shows a smaller run up in rents, a larger decline than asking rents, and an earlier timing of the peaks and troughs of the cycle.

\subsection{Distance to transportation infrastructure}

Since the distances to transportation infrastructure results were largely insignificant in the prior specification even though there is substantial clustering of properties around airports and rail lines, we consider the possibility that the impact of airports on real rents is nonlinear. Table 6 attempts to identify any spatial relationships not captured by the log-linear specification. For each type or mode of transportation a series of dummy variables is used indicating the 
distance to a specific type of transportation mode. The coefficients reported are from separate regression results for each mode. For example, all the rail results are estimated in one regression. The distance dummy variables are derived from the distribution of distance. The closest $1 \%, 5 \%, 25 \%$, and median were all tested and the most "successful" specifications are reported. For example, there is approximately a $5 \%$ premium in rents for property that is within 0.5 miles of a major airport, but no premium beyond that. This result is driven mostly by O'Hare airport where the premium is $7 \%$ for properties within 0.5 miles and is not found for Midway. The results also may reflect the unique characteristics of O'Hare-longer runways for airplanes to land on, more runways, international travel, and heavier air traffic. These findings are consistent with the clustering of property around O'Hare airport seen in Fig. 1. The results on Midway are all statistically insignificant.

Table 6. Distance to transportation infrastructure specification tests. Coefficient t-statistics

\section{Major airports}

Distance $<0.5$

$0.5 \leq$ Distance $<1.0$

$1.0 \leq$ Distance $<2.0$

O'Hare

Distance $<0.5$

$0.5 \leq$ Distance $<1.0$

$1.0 \leq$ Distance $<2.0$

Midway

Distance $<0.5$

$0.5 \leq$ Distance $<1.0$

$1.0 \leq$ Distance $<2.0$

Rail

Distance $<0.02$

$0.02 \leq$ Distance $<0.04$

$0.04 \leq$ Distance $<0.10$

$0.10 \leq$ Distance $<0.14$

Interstate highway

Distance $<\mathbf{0 . 2 0}$

$0.20 \leq$ Distance $<0.50$

Water ports

Distance $<4$

$4 \leq$ Distance $<6$

$6 \leq$ Distance $<18$

$18 \leq$ Distance $<22$

$\begin{array}{ll}0.049 * * * & 2.83 \\ -0.055 & -1.27 \\ -0.034 * * & -2.38 \\ & \\ 0.068 * * * & 3.57 \\ -0.013 & -0.53 \\ -0.024 & -1.30\end{array}$

$\begin{array}{ll}0.052 & 0.36\end{array}$

$\begin{array}{ll}-0.206 & -1.40\end{array}$

$-0.032$

$-0.64$

$\begin{array}{ll}-0.001 & -0.03\end{array}$

$0.023 \quad 0.65$

$0.014 \quad 0.70$

$\begin{array}{ll}-0.014 & -0.68\end{array}$

Intermodal points

0.050* $\quad 1.79$

$\begin{array}{ll}-0.002 & -0.07\end{array}$

$0.048 \quad 0.45$

$-0.144 * \quad-1.74$

$0.013 \quad 0.25$

$0.045 \quad 0.96$

Regional Science and Urban Economics, Vol 56 (January 2016): pg. 34-45. DOI. This article is @ Elsevier and permission has been granted for this version to appear in e-Publications@Marquette. Elsevier does not grant permission for this article to be further copied/distributed or hosted elsewhere without the express permission from Elsevier. 
NOT THE PUBLISHED VERSION; this is the author's final, peer-reviewed manuscript. The published version may be accessed by following the link in the citation at the bottom of the page.

Distance $<0.07$

$0.07 \leq$ Distance $<0.20$

$0.20 \leq$ Distance $<\mathbf{0 . 8 0}$
Coefficient

$-0.004$

$-0.022$

$-0.005$ t-statistics

$-0.14$

$-0.54$

$-0.23$

Distance is measured in miles. The set of dummy variables for each type (for example all dummy variables associated with water ports) of infrastructure is tested separately and added to the fixed effects results reported in Table 5.

*Coefficient is significant at the $10 \%$ level in a $t$-tailed test.

$* *$ Coefficient is significant at the $5 \%$ level in a $t$-tailed test.

$* * *$ Coefficient is significant at the $1 \%$ level in a $t$-tailed test.

There is little or no evidence that the clustering around other transportation infrastructure (i.e., rails, water ports, or intermodal points) is capitalized into real rents. The coefficients on the distance dummies for rail and intermodal points are all insignificant. This is a surprising result because the vast majority of industrial properties are close to rail lines. Approximately $25 \%$ of our properties are within 0.11 of a mile from a rail line and $50 \%$ are within 0.30 of a mile. Many of these industrial buildings back onto, or face, a rail line. One potential explanation is that other potential users of the location (e.g., hotel, apartment, single family home, or retail) may be more sensitive to the disamenities associated with being near transportation infrastructure. These factors include air quality, noise, vibrations, and light (especially during the nighttime hours). As a result, industrial property naturally outbids other property types for locations close to rail lines, intermodal points, and airports (except O'Hare).

In addition, only one of the water port coefficients (i.e., properties within 4 to 6 miles) is statistically significant and is negative indicating that real rents are actually lower than properties in a 4 to 6 mile distance. At least in this sample, industrial property is not clustered around water ports. This result likely is derived from unmeasured features of those neighborhoods 4 to 6 miles distance to the ports. There is some weak evidence that being very close to an interstate highway is associated with a $5 \%$ premium. This likely reflects the benefits of being near to the road system used in trucking.

\subsection{Lease term structure}

Table 7 provides some additional evidence that leases pay rent premiums when the leases last a long time. We also test to see if the

Regional Science and Urban Economics, Vol 56 (January 2016): pg. 34-45. DOI. This article is @ Elsevier and permission has been granted for this version to appear in e-Publications@Marquette. Elsevier does not grant permission for this article to be further copied/distributed or hosted elsewhere without the express permission from Elsevier. 
term structure premium is stable through the business cycle. If longterm leases reflect market expectations about future short term rental rates then the term structure may be positively sloped in some time periods and negatively sloped in different time periods. However, the results only find a positively sloped term structure.

\section{Table 7. Lease term structure specification tests.}

Coefficient

t-statistics

Lease term

1. Lease years

2. Log(lease years)

Lease term by time

3. Lease years

2003-2006

2007-2008

2009-2010

2010-2012

4. Log(lease years)

2003-2006

2007-2008

2009-2010

2010-2012

$\begin{array}{ll}0.019 * * * & 4.14 \\ 0.047 * * & 2.33 \\ & \\ & \\ 0.012 * & 1.86 \\ 0.007 & 0.52 \\ 0.023 * * * & 3.62 \\ 0.023 * * * & 3.60 \\ & \\ 0.039 & 1.19 \\ 0.024 & 0.53 \\ 0.057 * * & 2.07 \\ 0.051 * * & 2.14\end{array}$

Four different specifications are tested as indicated by the number in the first column. The base specification is the fixed effects results reported in Table 5 except that the continuous version of lease term is included. This reduces the sample to 1,442 leases. All other unreported coefficient estimates are economically similar.

*Coefficient is significant at the $10 \%$ level in a $t$-tailed test.

$* *$ Coefficient is significant at the $5 \%$ level in a $t$-tailed test.

$* * *$ Coefficient is significant at the $1 \%$ level in a $t$-tailed test.

To test for the stability of the results over time a continuous version of the lease term is included. This reduces the sample size to a little over 1440 lease transactions but allows a more parsimonious specification. The regression results indicate that longer term leases, whether measured in years or in the log of years, are associated with higher rental rates. In particular, the log specification indicates that a $10 \%$ increase in lease term is associated with a $0.5 \%$ increase in rents. The linear specification indicates that an increase in the lease term by 3 years is also associated with an increase in rents of approximately $0.6 \%$.

The next part of the table tests for the stability of the results through the business cycle. Under the expectations hypothesis, rents

Regional Science and Urban Economics, Vol 56 (January 2016): pg. 34-45. DOI. This article is (c) Elsevier and permission has been granted for this version to appear in e-Publications@Marquette. Elsevier does not grant permission for this article to be further copied/distributed or hosted elsewhere without the express permission from Elsevier. 
on long-term leases reflect expectations of future short term lease rents. Therefore, if expectations of future rents change we should also expect the shape of the lease term structure to change. To test for this, the next set of results interact lease term with different time periods (i.e., years when the lease starts). All specifications show that the term structure is steepest in 2009 through 2012 and flatter and statistically insignificant in 2007 and 2008. Consistent with the expectations hypothesis, at the peak and turning point of the rents the term structure was its flattest. However, by 2009, the market started to experience a steeper term structure but rents continued to decline.

In summary, the lease term results indicate an upward sloping term structure. Longer leases pay a premium. However, the premium varies during the business cycle and is at its largest after the peak of the cycle. There are two alternative interpretations of this result. The first is that under the expectations hypothesis these results indicate that market participants did adjust rental rate expectations around the peak of the market; however, after the decline continued, participants became too optimistic about a recovery in the market. An alternative is that landlords perceived more market risk as the depth of the recession became apparent and see greater risk for long-term commitments. Therefore landlords required higher risk premiums. It is beyond the scope of this paper to identify which of these two interpretations is more correct, but both perceptions of risk and perception of future rental rates likely vary systematically over the business cycle.

\section{Conclusion}

This paper estimates a hedonic model of commercial industrial property rents in the Chicago metropolitan area. From the results, we create a constant quality index of industrial property rents and find that rents declined by almost $25 \%$ from the peak in 2008 to trough in the first half of 2011. Since then rents have rebounded a little. The use of asking and average rents is shown to miss and lag market turning points. There is also evidence that average rents overstated the run up in rents before the peak and over stated the reduction in rents as they declined.

Regional Science and Urban Economics, Vol 56 (January 2016): pg. 34-45. DOI. This article is (c) Elsevier and permission has been granted for this version to appear in e-Publications@Marquette. Elsevier does not grant permission for this article to be further copied/distributed or hosted elsewhere without the express permission from Elsevier. 
The hedonic results indicate the importance of creating a constant quality rent index that holds constant both property, location, and lease characteristics. In particular, the attributes of the property and lease performed as expected, with more parking, more drive-ins, newer buildings, and smaller leases (in terms of square feet leased) all being associated with rent premiums. Industrial property used for warehouse space pays the lowest rent while space used for office and retail space pays higher rates. Full service leases pay premiums relative to net leases and long-term leases also pay substantial premiums. Leases with longer terms tend to pay a premium but it was smallest at the peak of the cycle and largest a few years after the peak. These results likely reflect systematic changes in rental rate expectations and perceptions of risk over the cycle.

Measures such as access to the interstate highway system, rail lines, intermodal points, and airports are shown to provide little explanatory power despite the clustering of property around these transportation modes. The premiums that are identified are highly nonlinear. For example, rent premiums are found for only being very close (within one-half a mile) to O'Hare airport. There was no consistent relationship between rent and being close to the other major airports in the region (Midway and Mitchell airport in nearby Milwaukee, Wisconsin). Similarly, the benefits of locating near to an interstate highway are small. There is also no rent premium associated with being close to a rail road line, a water port on Lake Michigan or an intermodal point, a location where goods can change modes of transportation (for example, rail to air, or port). We interpret these results as indicating that industrial warehouses may have had productive reasons for locating close to transportation infrastructure in the past but these confer few financial benefits today. Instead, the disamenities created by noise, vibrations, and pollution of major transportation arteries or nodes cancel out any benefits (productivity or non-property cost). In contrast, transportation for workers and other local market characteristics do seem to be capitalized into lease rents as an effective worker amenity.

\section{Appendix A.}

In the OLS model, the errors, $y$, are assumed to be randomly distributed with mean zero and constant variance. For the spatial error

Regional Science and Urban Economics, Vol 56 (January 2016): pg. 34-45. DOI. This article is (c) Elsevier and permission has been granted for this version to appear in e-Publications@Marquette. Elsevier does not grant permission for this article to be further copied/distributed or hosted elsewhere without the express permission from Elsevier. 
model (SEM), $Y$ is related to spatially proximate errors through the weight matrix, $W$. Specifically, the error becomes: $y=\lambda W \gamma+\xi$, where $W$ is the normalized spatial weight matrix, $\lambda$ is the spatial error coefficient, and $\xi$ is a random error term with zero mean and constant variance. Note that if $\lambda=0$, then the SEM defaults to the OLS model. A spatial weight matrix is used to define contiguity as the 10 closest neighbors in the sample. Two spatial models were initially explored: the spatial autoregressive model (SAR) and the spatial error model (SEM).

The Lagrange multiplier-lag (LM-Lag) and Lagrange multipliererror (LM-Error) tests were both significant, but the robust LM-Error test gave a higher significance level tan the robust LM-Lag test, suggesting that the SEM model is preferred. The SEM was estimated employing the general methods of moments method of estimation. The findings are nearly identical to those SEM estimates generated using maximum likelihood. The Moran I test on the residuals of the OLS model indicated that the null hypothesis of no spatial autocorrelation can be rejected (Moran $\mathrm{I}=0.1673 ; p$-value $=0.00$ ).

\section{Table A1. Part 1: spatial error model (SEM) results-property} characteristics.

\begin{tabular}{|c|c|c|c|}
\hline Category & $\begin{array}{c}\text { Variable } \\
\text { Intercept }\end{array}$ & $\begin{array}{l}\text { Coefficient } \\
-3.0807^{* * *}\end{array}$ & $\begin{array}{l}t \text {-score } \\
-3.859\end{array}$ \\
\hline Property & Parking ratio $=$ & $-0.0461^{* * *}$ & -2.705 \\
\hline \multirow[t]{6}{*}{ (excluded: park ratio > 2) } & Parking ratio $\leq 1.0$ & $-0.1025^{* * *}$ & -5.259 \\
\hline & $1.0<$ Parking ratio $<=1.5$ & $-0.0666^{* * *}$ & -3.637 \\
\hline & $1.5<$ Parking ratio $<=2.0$ & -0.0077 & -0.327 \\
\hline & No. drive-ins/1000 square feet & $0.1030^{* * *}$ & 3.917 \\
\hline & Year built (100s) & $0.0036^{* * *}$ & 9.009 \\
\hline & Log(lease square feet) & $-0.1513^{* * *}$ & -23.495 \\
\hline \multirow[t]{6}{*}{ (excluded: ceiling $<=12$ ) } & Ceiling $=$ & 0.0417 & 1.349 \\
\hline & $12<$ Ceiling $\leq 14$ & 0.0356 & 1.632 \\
\hline & $14<$ Ceiling $\leq 16$ & $0.0649^{* * *}$ & 2.906 \\
\hline & $16<$ Ceiling $\leq 20$ & $0.0409^{*}$ & 1.795 \\
\hline & $20<$ Ceiling $\leq 25$ & $0.0924^{* * *}$ & 3.375 \\
\hline & Ceiling $\geq 25$ & $0.0755^{* *}$ & 2.319 \\
\hline \multirow[t]{2}{*}{ (excluded: no cranes) } & Cranes & $-0.0851^{* * *}$ & -2.947 \\
\hline & Rail $=$. & $0.0321^{* *}$ & 2.182 \\
\hline (excluded: no rail) & Rail & -0.0166 & -0.711 \\
\hline \multirow[t]{3}{*}{ (excluded: not owned) } & Owned & $0.1939^{* * *}$ & 4.720 \\
\hline & Log(dist to water port) & -0.1846 & -0.915 \\
\hline & Log(dist to airport) & $-0.0221^{* * *}$ & -2.581 \\
\hline
\end{tabular}

Regional Science and Urban Economics, Vol 56 (January 2016): pg. 34-45. DOI. This article is (C) Elsevier and permission has been granted for this version to appear in e-Publications@Marquette. Elsevier does not grant permission for this article to be further copied/distributed or hosted elsewhere without the express permission from Elsevier. 
NOT THE PUBLISHED VERSION; this is the author's final, peer-reviewed manuscript. The published version may be accessed by following the link in the citation at the bottom of the page.

Category

\begin{tabular}{lll}
\multicolumn{1}{c}{$\quad$ Variable } & \multicolumn{1}{c}{ Coefficient } & \multicolumn{1}{c}{ t-score } \\
Intercept & \multicolumn{1}{c}{$\mathbf{3 . 0 8 0 7 ^ { * * * }}$} & $\mathbf{- 3 . 8 5 9}$ \\
Log(dist to small airport) & -0.0048 & -0.521 \\
Log(dist to rail) & 0.0009 & 0.167 \\
Log(dist to interstate) & -0.0010 & -0.134 \\
Log(dist to intermodal) & 0.0148 & 1.635 \\
Number of observations & 2645 & \\
Adjusted $R^{2}$ & 0.5854 &
\end{tabular}

Dependent variable: log(real rent per square foot per year, deflated by CPI-U). Part 1 and Part 2 are estimated in one regression and reported in two tables to improve readability only.

*Coefficient is significant at the $10 \%$ level in a $t$-tailed test.

$* *$ Coefficient is significant at the $5 \%$ level in a $t$-tailed test.

$* * *$ Coefficient is significant at the $1 \%$ level in a $t$-tailed test.

Table A1. Part 2: spatial error model (SEM) results.

\begin{tabular}{|c|c|c|c|}
\hline Category & Variable & Coefficient & t-statistics \\
\hline Lease (excluded: direct leased) & Subleased & -0.0632 & -1.552 \\
\hline (excluded: multi-tenant) & Single tenant & $0.0456^{* * *}$ & 2.552 \\
\hline \multirow[t]{2}{*}{ (excluded: net) } & Full service & $0.0808^{* * *}$ & 4.561 \\
\hline & Modified gross & $0.0682^{* * *}$ & 4.789 \\
\hline \multirow[t]{3}{*}{ (excluded: warehouse) } & Office & $0.3019^{* * *}$ & 10.091 \\
\hline & Flex & 0.0063 & 0.184 \\
\hline & Retail & $0.1464^{* * *}$ & 2.990 \\
\hline \multirow[t]{7}{*}{ (excluded: lease term $<1$ year) } & Lease term $=$. & 0.0350 & 1.415 \\
\hline & Lease term $<2$ years & -0.0227 & -0.807 \\
\hline & Lease term $<3$ years & -0.0167 & -0.655 \\
\hline & Lease term $<4$ years & 0.0218 & 0.697 \\
\hline & Lease term $<5$ years & 0.0120 & 0.368 \\
\hline & Lease term $<10$ years & 0.0378 & 1.407 \\
\hline & Lease term $\geq 10$ years & $0.1409^{* * *}$ & 4.011 \\
\hline Time & Year $\leq 2003$ & $0.3504^{* * *}$ & 7.361 \\
\hline (excluded: & Year $=2004$ & $0.2847^{* * *}$ & 5.750 \\
\hline \multirow[t]{13}{*}{ year = $2012-2)$} & Year $=2005$ & $0.2687^{* * *}$ & 5.558 \\
\hline & Year $=2006$ & $0.2926^{* * *}$ & 6.441 \\
\hline & Year $=2007-1$ & $0.2720^{* * *}$ & 6.121 \\
\hline & Year $=2007-2$ & $0.2632^{* * *}$ & 6.087 \\
\hline & Year $=2008-1$ & $0.2271^{* * *}$ & 5.418 \\
\hline & Year $=2008-2$ & $0.2171^{* * *}$ & 5.125 \\
\hline & Year $=2009-1$ & $0.1816^{* * *}$ & 4.456 \\
\hline & Year $=2009-2$ & $0.1229^{* * *}$ & 3.120 \\
\hline & Year $=2010-1$ & $0.0876^{* *}$ & 2.283 \\
\hline & Year $=2010-2$ & $0.0754^{* *}$ & 1.971 \\
\hline & Year $=2011-1$ & -0.0257 & -0.680 \\
\hline & Year $=2011-2$ & 0.0231 & 0.601 \\
\hline & Year $=2012-1$ & 0.0026 & 0.067 \\
\hline Local market & Nonwhite & $-0.1834^{* *}$ & -3.421 \\
\hline
\end{tabular}

Regional Science and Urban Economics, Vol 56 (January 2016): pg. 34-45. DOI. This article is @ Elsevier and permission has been granted for this version to appear in e-Publications@Marquette. Elsevier does not grant permission for this article to be further copied/distributed or hosted elsewhere without the express permission from Elsevier. 
NOT THE PUBLISHED VERSION; this is the author's final, peer-reviewed manuscript. The published version may be accessed by following the link in the citation at the bottom of the page.

Category

Spatial error lag

Dependent variable: log(real rent per square foot per year, deflated by CPI-U). Part 1 and Part 2 are estimated in one regression and reported in two tables to improve readability only.

*Coefficient is significant at the $10 \%$ level in a $t$-tailed test.

$* *$ Coefficient is significant at the $5 \%$ level in a $t$-tailed test.

$* * *$ Coefficient is significant at the $1 \%$ level in a $t$-tailed test.

\section{Table A2. Submarket areas and fixed effects estimates.}

\begin{tabular}{|c|c|c|c|}
\hline Market & Description & Coefficient & t-statistics \\
\hline mkt1 & Boone County & Excluded & \\
\hline mkt2 & Central Kane/Dupage & $-0.226^{*} * * *$ & -4.46 \\
\hline mkt3 & Central Will & $-0.311 * * *$ & -5.86 \\
\hline mkt4 & Far South Cook & $-0.336 * * *$ & -6.15 \\
\hline mkt5 & Grundy County & $-0.346 * * *$ & -10.29 \\
\hline & I-39 Corridor LaSalle, Winnebago, Lee, and Ogle Counties & & \\
\hline mkt7 & I-88 West & $-0.279 * * *$ & -6.49 \\
\hline mkt8 & Indiana & $-0.346 * * *$ & -4.88 \\
\hline mkt9 & Jasper County & $-0.469 * * *$ & -6.08 \\
\hline mkt10 & Joliet Area & $-0.342 * * *$ & -7.04 \\
\hline mkt11 & Kenosha East and West & $-0.288 * * *$ & -3.94 \\
\hline mkt12 & McHenry County & $-0.425 * * *$ & -7.92 \\
\hline mkt13 & Near SW Suburbs & $-0.387 * * *$ & -4.14 \\
\hline mkt14 & Near South Cook & $-0.347 * * *$ & -4.46 \\
\hline mkt15 & North Chicago & -0.173 & -1.45 \\
\hline mkt16 & North Cook & -0.113 & -1.34 \\
\hline mkt17 & North DuPage & $-0.139 * *$ & -2.39 \\
\hline mkt18 & North I-55 & $-0.283 * * *$ & -3.45 \\
\hline mkt19 & North Kane/I-90 & $-0.189 * * *$ & -5.07 \\
\hline mkt20 & North Lake County & $-0.250 * * *$ & -5.72 \\
\hline mkt21 & Northwest Cook & $-0.130 * *$ & -2.12 \\
\hline mkt22 & O'Hare & $-0.174 * *$ & -2.34 \\
\hline mkt23 & Porter County & $-0.584 * * *$ & -10.96 \\
\hline mkt24 & South Chicago & $-0.509 * * *$ & -4.19 \\
\hline mkt25 & South I-55 & $-0.196 * * *$ & -3.80 \\
\hline mkt26 & South Lake County & $-0.175^{* * *}$ & -3.25 \\
\hline mkt27 & West Cook North and South & $-0.189 * *$ & -2.15 \\
\hline mkt28 & West Suburbs & $-0.185^{* *}$ & -2.72 \\
\hline mkt29 & Other & 0.012 & 0.15 \\
\hline
\end{tabular}

Coefficient $t$-statistics

$-0.0015-0.829$

$-0.0681^{* * *}-3.166$

$-0.0871^{* * *}-3.616$

$-0.0299^{* * *}-2.579$

$0.0132 \quad 0.075$

$0.5079^{* * *} \quad 4.335$

\begin{tabular}{lll} 
& \multicolumn{1}{c}{ Coefficient } & t-statistics \\
Median age & -0.0015 & -0.829 \\
Density & $-0.0681^{* * *}$ & -3.166 \\
Household size & $-0.0871^{* * *}$ & -3.616 \\
Log(dist to commuter rail) & $-0.0299^{* * *}$ & -2.579 \\
Log(dist to city center) & 0.0132 & 0.075 \\
Lambda & $0.5079^{* * *}$ & 4.335
\end{tabular}


NOT THE PUBLISHED VERSION; this is the author's final, peer-reviewed manuscript. The published version may be accessed by following the link in the citation at the bottom of the page.

These are submarkets within the Chicago metropolitan area as defined by CoStar. See Fig. A1 for a map of these submarkets. These are the fixed effects estimates for Table $5 a$ and Table 5b.

*Coefficient is significant at the $10 \%$ level in a $t$-tailed test.

$* *$ Coefficient is significant at the $5 \%$ level in a $t$-tailed test.

$* * *$ Coefficient is significant at the $1 \%$ level in a $t$-tailed test.

\section{References}

Ambrose, 1990, B.W. Ambrose. An analysis of the factors affecting light industrial property. J. Real Estate Res., 5 (3) (1990), pp. 355-370

Ambrose and Yildirim, 2008. B.W. Ambrose, Y. Yildirim. Credit risk and the term structure of lease rates: a reduced form approach. J. Real Estate Financ. Econ., 37 (3) (2008), pp. 281-298

Anglin, 1994. P.M. Anglin. Contracts for the sale of residential real estate. $J$. Real Estate Financ. Econ., 8 (3) (1994), pp. 195-211

Benjamin et al., 1998. John Benjamin, G. Donald Jud, Daniel T. Winkler. The supply adjustment process in retail space markets. J. Real Estate Res., 15 (3) (1998), pp. 297-308

Blank and Winnick, 1953. D.M. Blank, L. Winnick. The structure of the housing market. Q. J. Econ., 67 (2) (1953), pp. 181-208

Bond et al., 2008.Shaun Bond, Pavlos Loizou, Patrick McAllister. Lease maturity and initial rent: is there a term structure for UK commercial property lease? J. Real Estate Financ. Econ., 36 (4) (2008), pp. 451469

Brounen and Jennen, 2009. Dirk Brounen, Maarten Jennen. Asymmetric properties of office rent adjustment. J. Real Estate Financ. Econ., 39 (3) (2009), pp. 336-358

Brunauer et al., 2010. W.A. Brunauer, S. Lang, P. Wechselberger, S. Bienert. Additive hedonic regression models with spatial scaling factors: an application for rents in Vienna. J. Real Estate Financ. Econ., 41 (4) (2010), pp. 390-411

Buttimer and Ott, 2007. R. Buttimer, S.H. Ott. Commercial real estate valuation, development and occupancy under leasing uncertainty. Real Estate Econ., 35 (1) (2007), pp. 21-56

Chegut et al., 2011. Andrea Chegut, Piet Eichholtz, Nils Kok. The Value of Green Buildings: New Evidence from the United Kingdom. Presented at the Allied Social Science Association January Meeting 2012 (2011) (Downloaded in December 2012 from www.sirp.se/getfile.ashx?cid $=280784 \& c c=3 \&$ refid $=34$ )

Clapham and Gunnelin, 2003. Eric Clapham, Åke Gunnelin. Rental expectations and the term structure of lease rates. Real Estate Econ., 31 (4) (2003), pp. 647-670

Regional Science and Urban Economics, Vol 56 (January 2016): pg. 34-45. DOI. This article is (C) Elsevier and permission has been granted for this version to appear in e-Publications@Marquette. Elsevier does not grant permission for this article to be further copied/distributed or hosted elsewhere without the express permission from Elsevier. 
NOT THE PUBLISHED VERSION; this is the author's final, peer-reviewed manuscript. The published version may be

accessed by following the link in the citation at the bottom of the page.

Cohen and Paul, 2007.Jeffrey P. Cohen, Catherine Morrison Paul. The impacts of transportation infrastructure on property values: a higher-order spatial econometrics approach. J. Reg. Sci., 47 (3) (2007), pp. 457478

Conroy and Milosch, 2011. Stephen J. Conroy, Jennifer L. Milosch. An estimation of the coastal premium for residential housing prices in San Diego County. J. Real Estate Financ. Econ., 42 (2) (2011), pp. 211228

Cutter and DeWoody, 2010. Bowman Cutter IV, DeWoody. Parking externalities in commercial real estate. Real Estate Econ., 38 (2) (2010), pp. 197-223

De Francesco, 2008. Anthony J. De Francesco. Time-series characteristics and long-run equilibrium for major Australian office markets. Real Estate Econ., 36 (2) (2008), pp. 371-402

DiJohn, 2010. Joseph DiJohn. Chicago's CREATE rail program: a successful public-private partnership. Presented at the Canadian Transportation Research Forum 45th Annual Conference in Toronto, Canada (2010) (Downloaded on December 2012 from http://www.utc.uic.edu/freight/Chicago'spercent20CREATE percent20for percent20CTRF22.pdf)

Eberts, 1981. Randall W. Eberts. An empirical investigation of intraurban wage gradients. J. Urban Econ., 10 (1) (1981), pp. 50-60

Eichholtz et al., 2010. Piet Eichholtz, Nils Kok, John M. Quigley. Doing well by doing good? green office buildings. Am. Econ. Rev., 100 (5) (2010), pp. 2492-2509

Englund et al., 2004. Peter Englund, Åke Gunnelin, Martin Hoesli, Bo Söderberg. Implicit forward rents as predictors of future rents. Real Estate Econ., 32 (2) (2004), pp. 182-215

Englund et al., 2008. Peter Englund, Åke Gunnelin, Patric H. Hendershott, Bo Söderberg. Adjustment in property space markets: taking long-term leases and transaction costs seriously. Real Estate Econ., 36 (1) (2008), pp. 81-109

Fehribach et al., 1993. F.A. Fehribach, R.C. Rutherford, M.E. Eakin. An analysis of the determinants of industrial property valuation. J. Real Estate Res., 8 (3) (1993), pp. 365-376

Griliches, 1971. Zvi Griliches. Hedonic price indexes of automobiles: an econometric analysis of quality change. Zvi Griliches (Ed.), Price Indexes and Quality Change, Cambridge University Press, Cambridge (1971)

Griliches, 1967. Zvi Griliches. Hedonic price indexes revisited: some notes on the state of the art. Proceedings of the Business and Economic Statistics Section, American Statistical Association (1967), pp. 324332

Regional Science and Urban Economics, Vol 56 (January 2016): pg. 34-45. DOI. This article is @ Elsevier and permission has been granted for this version to appear in e-Publications@Marquette. Elsevier does not grant permission for this article to be further copied/distributed or hosted elsewhere without the express permission from Elsevier. 
NOT THE PUBLISHED VERSION; this is the author's final, peer-reviewed manuscript. The published version may be accessed by following the link in the citation at the bottom of the page.

Gunnelin and Soderberg, 2003. Åke Gunnelin, Bo Soderberg. Term structures in the office rental market in Stockholm. J. Real Estate Financ. Econ., $26(2 / 3)(2003)$, pp. 241-265

Hendershott et al., 2002a. Patric H. Hendershott, Bryan D. MacGregor, Raymond Tse. Estimation of the rental adjustment process. Real Estate Econ., 30 (2) (2002), pp. 165-183

Hendershott et al., 2002b. Patric H. Hendershott, Bryan D. MacGregor, Michael James White. Explaining real commercial rents using an error correction model with panel data. J. Real Estate Financ. Econ., 24 (1\&2) (2002), pp. 59-87

Immergluck and Smith, 2006. Dan Immergluck, Geoff Smith. The external costs of foreclosure: the impact of single-family mortgage foreclosures on property values. Housing Policy Debate, 17 (1) (2006), pp. 57-79

Jennen and Brounen, 2009. Maarten Jennen, Dirk Brounen. The effect of clustering on office rents: evidence from the Amsterdam market. Real Estate Econ., 37 (2) (2009), pp. 185-208

Lancaster, 1966. Kelvin J. Lancaster. A new approach to consumer theory. J. Polit. Econ., 74 (1966), pp. 132-157

McMillan and Redfearn, 2010. Daniel P. McMillan, Christian L. Redfearn. Estimation and hypothesis testing for nonparametric hedonic house price functions. J. Reg. Sci., 50 (3) (2010), pp. 712-733

McMillan and Singell, 1992. Daniel P. McMillan, Larry Singell Jr. Work location, residence location, and the intraurban wage gradient. J. Urban Econ., 32 (2) (1992), pp. 195-213

Miller et al., 2008. Norm Miller, Jay Spivey, Andrew Florance. Does green pay off? J. Real Estate Portf. Manag., 14 (4) (2008), pp. 385-400

Munneke and Slade, 2000. Henry Munneke, Barrett Slade. Empirical study of sample-selection bias in indices of commercial real estate. J. Real Estate Financ. Econ., 21 (1) (2000), pp. 45-64

Munneke and Slade, 2001. Henry Munneke, Barrett Slade. A metropolitan transaction-based commercial price index: a time-varying parameter approach. Real Estate Econ., 29 (1) (2001), pp. 55-84

Rosen, 1974. Sherwin Rosen. Hedonic prices and implicit markets: product differentiation in pure competition. J. Polit. Econ., 82 (Jan./Feb) (1974), pp. 34-55

Ryan, 2005. Sherry Ryan. The value of access to highways and light rail transit: evidence for industrial and office firms. Urban Stud., 42 (4) (2005), pp. 751-764

Shilling et al., 1987. James D. Shilling, C.F. Sirmans, John B. Corgel. Price adjustment process for rental office space. J. Urban Econ., 22 (1) (1987), pp. 90-100

Regional Science and Urban Economics, Vol 56 (January 2016): pg. 34-45. DOI. This article is (c) Elsevier and permission has been granted for this version to appear in e-Publications@Marquette. Elsevier does not grant permission for this article to be further copied/distributed or hosted elsewhere without the express permission from Elsevier. 
NOT THE PUBLISHED VERSION; this is the author's final, peer-reviewed manuscript. The published version may be

accessed by following the link in the citation at the bottom of the page.

Sivitanidou, 1995. Rena Sivitanidou. Urban spatial variations in commercial rents: the role of spatial amenities and commercial zoning. J. Urban Econ., 38 (1) (1995), pp. 23-49

Sivitanidou and Sivitanides, 1995. Rena Sivitanidou, Petros Sivitanides. Industrial rent differentials: the case of Greater Los Angeles. Environ. Plan., A27 (7) (1995), pp. 1133-1146

Sivitanidou and Wheaton, 1992. Rena Sivitanidou, William C. Wheaton. Wage and rent capitalization in the commercial real estate market. J. Urban Econ., 31 (2) (1992), pp. 206-229

Slade, 2000. Barrett A. Slade. Office rent determinants during market decline and recovery. J. Real Estate Res., 20 (3) (2000), pp. 357-380

Timothy and Wheaton, 2001. Darren Timothy, William Wheaton. Intra-urban wage variation, employment location and commuting times. J. Urban Econ., 50 (2) (2001), pp. 338-366

Waugh, 1928. F.V. Waugh. Quality factors influencing vegetable prices. J. Farm Econ., 10 (1928), pp. 185-196

Webb and Fisher, 1996. R. Brian Webb, Jeffrey Fisher. Development of an effective rent (lease) index for Chicago CBD. J. Urban Econ., 39 (1) (1996), pp. 1-19

Wheaton et al., 2009. William Wheaton, Mark Baranski, Cesarina Templeton. 100 years of commercial real estate prices in Manhattan. Real Estate Econ., 37 (1) (2009), pp. 69-83

Wheaton and Torto, 1988. William Wheaton, Raymond G. Torto. Vacancy rates and the future of office rents. J. Am. Real Estate Urban Econ. Assoc., 16 (4) (1988), pp. 430-436

Wheaton et al., 1997. William Wheaton, Raymond Torto, Peter Evans. The cyclic behavior of the greater London office market. J. Real Estate Financ. Econ., 15 (1) (1997), pp. 77-92

Wiley et al., 2010. Jonathan Wiley, Justin Benefield, Ken Johnson. Green design and the market for commercial office space. J. Real Estate Financ. Econ., 41 (2) (2010), pp. 228-243

Williams, 1998. J.T. Williams. Agency and brokerage of real assets in competitive equilibrium. Rev. Financ. Stud., 11 (2) (1998), pp. 239280

i We would like to thank Maria Ibanez and Andrew Sinclair for their diligent help and good humor throughout the project and the participants at the Homer Hoyt Institute, Maury Seldin Advanced Studies Institute: Weimer School of Advanced Studies in Real Estate and Land Economics Seminar Series, the Marquette University Economics Colloquium, and students and faculty of the George Washington University Graduate Program in Urban Sustainability.

Corresponding author. Tel.: + 14142881452.

Regional Science and Urban Economics, Vol 56 (January 2016): pg. 34-45. DOI. This article is (c) Elsevier and permission has been granted for this version to appear in e-Publications@Marquette. Elsevier does not grant permission for this article to be further copied/distributed or hosted elsewhere without the express permission from Elsevier. 
NOT THE PUBLISHED VERSION; this is the author's final, peer-reviewed manuscript. The published version may be accessed by following the link in the citation at the bottom of the page.

1Tel.: + 14142883339 .

2According to the Council of Supply Chain Management Professionals (CSCMP), expenditures on transportation were $\$ 688$ billion (4.8\% of GDP) and the cost of logistics was $\$ 1.1$ trillion (7.7\% of GDP) in the United States in 2009 (http://cscmp.org/press/fastfacts.asp).

3A different line of research more explicitly measures the supply and demand for space. For example, Blank and Winnick (1953) developed a model of the relationship between rents and vacancy rates in the housing market and the importance of unoccupied space and rents has been studied extensively, particularly for the US office markets (e.g., Shilling et al., 1987, and Wheaton and Torto, 1988). There is strong empirical evidence that rents go down when vacancy rates increase and employment decreases and that there is persistence in how rents evolve over time (Wheaton et al., 1997 and Brounen and Jennen, 2009).

4Commercial property rents have also been studied using different approaches, including first, a structural and stock adjustment framework at a micro or property level (e.g., Benjamin et al., 1998 and Wheaton et al., 1997); second, an error correction model that identifies long-run relationships and short-run dynamic responses to deviations from equilibrium in the same specification at the aggregate level (e.g., Hendershott et al., 2002a, Hendershott et al., 2002b, Brounen and Jennen, 2009 and De Francesco, 2008); third, repeat-sales transactions (e.g., Wheaton et al., 2009); and fourth, the Poisson model (e.g., Anglin, 1994, Williams, 1998 and Buttimer and Ott, 2007).

5Distance is measured as the shortest distance to the identified shape, boundary, or single point.

6 When considering amenities, this highest and best use axiom of urban location models implies that a more amenable location will be residential if the amenities are more highly valued by residential users than by industrial users, all else equal.

7The SEM was estimated employing the general methods of moments method of estimation. The findings are nearly identical to those SEM estimates generated using maximum likelihood.

8 Work by McMillan and Redfearn (2010) suggests that nonparametric methods such as geographically weighted regression (GWR) may be more efficient than OLS with locational fixed effects. Unfortunately, given the relatively small sample size, GWR proved to be unworkable in this application since subsamples did not permit inclusion of all categorical variables of interest (i.e., time dummies, lease term dummies, and structural dummies) unless the bandwidth was set to be overly inclusive. Thus, we include OLS with locational fixed effects, recognizing a potential loss of efficiency.

Regional Science and Urban Economics, Vol 56 (January 2016): pg. 34-45. DOI. This article is @ Elsevier and permission has been granted for this version to appear in e-Publications@Marquette. Elsevier does not grant permission for this article to be further copied/distributed or hosted elsewhere without the express permission from Elsevier. 
9Additional specification tests allowed the relationship between building age and rents to be nonlinear. The results indicate that, relative to newer building built in the 2000 s, very old buildings have large discounts of $18 \%$ to over $30 \%$ and buildings built in the 1960 s through the 1980 s have similar discounts ranging from 10 to $13 \%$, while buildings built in the 1990 s have a discount of $8 \%$. Hence, we find no evidence that very old buildings have a premium or an attenuation of the discount.

10To illustrate the precision of the index results see the coefficient estimates and the $95 \%$ confidence intervals below.

\begin{tabular}{rlll} 
Year & \multicolumn{1}{c}{ Coefficient } & \multicolumn{1}{c}{ Lower CI 95\% } & \multicolumn{1}{c}{ Upper CI 95\% } \\
Year $\leq 2003$ & 0.283 & 0.197 & 0.368 \\
Year $=2004$ & 0.232 & 0.146 & 0.318 \\
Year $=2005$ & 0.242 & 0.174 & 0.310 \\
Year $=2006$ & 0.244 & 0.160 & 0.327 \\
Year $=2007-1$ & 0.237 & 0.152 & 0.322 \\
Year $=2007-2$ & 0.216 & 0.141 & 0.292 \\
Year $=2008-1$ & 0.195 & 0.119 & 0.272 \\
Year $=2008-2$ & 0.187 & 0.111 & 0.263 \\
Year $=2009-1$ & 0.159 & 0.077 & 0.242 \\
Year $=2009-2$ & 0.096 & 0.015 & 0.178 \\
Year $=2010-1$ & 0.075 & -0.006 & 0.155 \\
Year $=2010-2$ & 0.065 & -0.022 & 0.151 \\
Year $=2011-1$ & -0.032 & -0.093 & 0.029 \\
Year $=2011-2$ & 0.019 & -0.053 & 0.090 \\
Year $=2012-1$ & -0.013 & -0.067 & 0.040
\end{tabular}

Regional Science and Urban Economics, Vol 56 (January 2016): pg. 34-45. DOI. This article is (C) Elsevier and permission has been granted for this version to appear in e-Publications@Marquette. Elsevier does not grant permission for this article to be further copied/distributed or hosted elsewhere without the express permission from Elsevier. 